\title{
Targeting of insect epicuticular lipids by the entomopathogenic fungus Beauveria bassiana: hydrocarbon oxidation within the context of a host-pathogen interaction
}

\author{
Nicolás Pedrini ${ }^{1}$, Almudena Ortiz-Urquiza ${ }^{2}$, Carla Huarte-Bonnet ${ }^{1}$, Shizhu Zhang ${ }^{2,3}$ and \\ Nemat O. Keyhani ${ }^{2 *}$
}

${ }^{1}$ Facultad de Ciencias Médicas, Instituto de Investigaciones Bioquímicas de La Plata (CCT La Plata CONICET-UNLP), La Plata, Argentina

2 Department of Microbiology and Cell Science, University of Florida, Gainesville, FL, USA

${ }_{3}^{3}$ Jiangsu Key Laboratory for Microbes and Functional Genomics, Jiangsu Engineering and Technology Research Center for Microbiology, College of Life Sciences, Nanjing Normal University, Nanjing, China

\section{Edited by:}

Rachel N. Austin, Bates College, USA

\section{Reviewed by:}

Rachel N. Austin, Bates College, USA

Alan A. DiSpirito, Ohio State University, USA

*Correspondence:

Nemat O. Keyhani, Department of Microbiology and Cell Science,

University of Florida, Gainesville,

FL 32611, USA.

e-mail:keyhani@ufl.edu
Broad host range entomopathogenic fungi such as Beauveria bassiana attack insect hosts via attachment to cuticular substrata and the production of enzymes for the degradation and penetration of insect cuticle. The outermost epicuticular layer consists of a complex mixture of non-polar lipids including hydrocarbons, fatty acids, and wax esters. Long chain hydrocarbons are major components of the outer waxy layer of diverse insect species, where they serve to protect against desiccation and microbial parasites, and as recognition molecules or as a platform for semiochemicals. Insect pathogenic fungi have evolved mechanisms for overcoming this barrier, likely with sets of lipid degrading enzymes with overlapping substrate specificities. Alkanes and fatty acids are substrates for a specific subset of fungal cytochrome P450 monooxygenases involved in insect hydrocarbon degradation. These enzymes activate alkanes by terminal oxidation to alcohols, which are further oxidized by alcohol and aldehyde dehydrogenases, whose products can enter $\beta$-oxidation pathways. B. bassiana contains at least 83 genes coding for cytochrome P450s (CYP), a subset of which are involved in hydrocarbon oxidation, and several of which represent new CYP subfamilies/families. Expression data indicated differential induction by alkanes and insect lipids and four CYP proteins have been partially characterized after heterologous expression in yeast. Gene knockouts revealed a phenotype for only one (cyp52X1) out of six genes examined to date. CYP52X1 oxidizes long chain fatty acids and participates in the degradation of specific epicuticular lipid components needed for breaching the insect waxy layer. Examining the hydrocarbon oxidizing CYP repertoire of pathogens involved in insect epicuticle degradation can lead to the characterization of enzymes with novel substrate specificities. Pathogen targeting may also represent an important co-evolutionary process regarding insect cuticular hydrocarbon synthesis.

Keywords: B. basiana, entomopathogenic fungi, epicuticle, hydrocarbon degradation, cytochrome P450, hostpathogen coevolution

\section{INTRODUCTION}

Insect cuticles are a significant source of hydrocarbons in terrestrial ecosystems and remediation and turnover of these compounds is critical for the maintenance and flux of normal carbon cycles. Yeasts and filamentous fungi are known to degrade $n$-alkanes and although significant portions of the biochemical pathways regarding alkane catabolism have been described, much remains obscure. The insect epicuticle or waxy layer represents the first barrier to environmental threats including external compounds such as chemical and biological pesticides. This thin layer on the outer surface of the insect is comprised of a complex mixture of lipids that include abundant amounts of straight-chain and methyl-branched, saturated and unsaturated hydrocarbons.
Pathogenicity to invertebrates is represented by primitive fungi and is postulated to have arisen simultaneously with the emergence of insects approximately 500 million years ago (Berbee and Taylor, 2001). The ancient Chinese noted the lethal effects of fungi on silkworms and cicadas more than 2 millennia ago (Roberts and Humber, 1981) and Augustino Bassi in the 1830s used strains of Beauveria (bassi)ana as a model for his germ theory of disease in animals (Steinhaus, 1956). Due to their dispersal within most major fungal taxonomic groups, fungal-insect pathogens represent lifestyle adaptations that have likely evolved numerous times (Khachatourians, 1996; Goettel et al., 2000). B. bassiana has an exceptionally broad host range and is being studied for use as a biological control for a diverse range of insects (Figure 1). This 

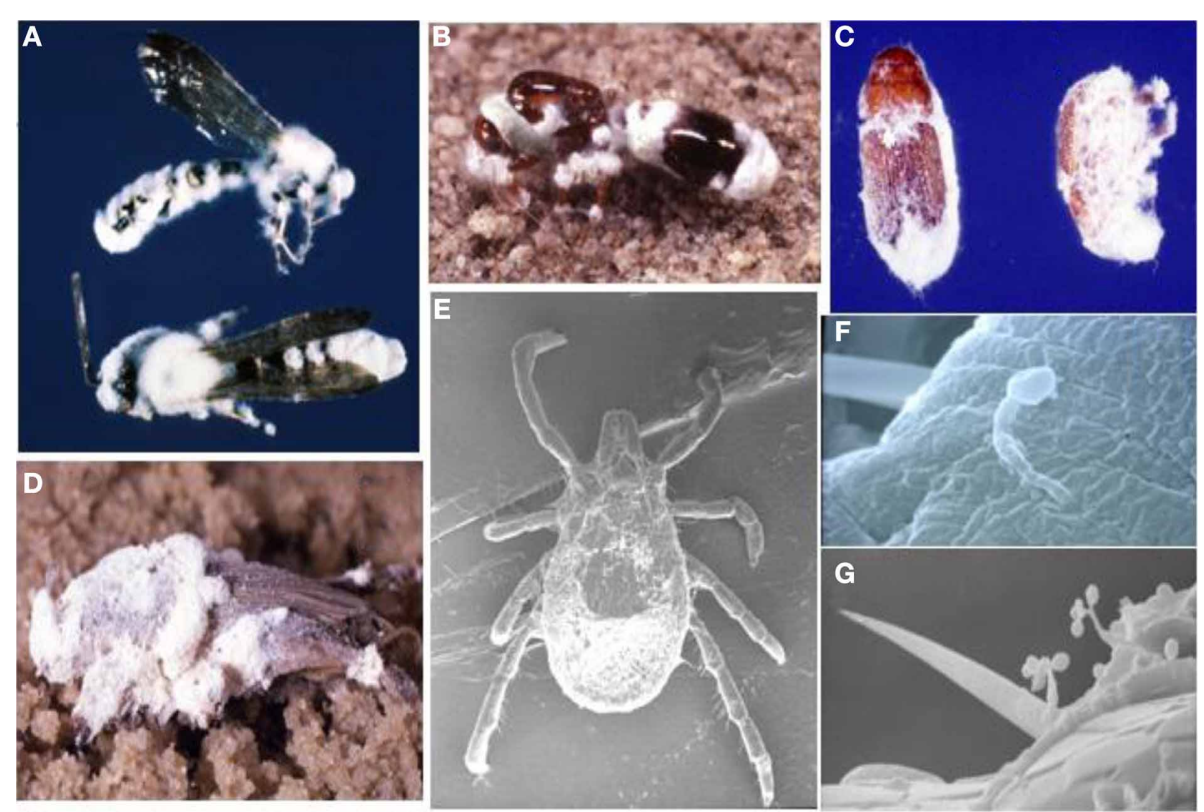

FIGURE 1 | B. bassiana has an exceptionally broad host range that spans across Arthropoda classes, from insects including; wasps (A), fire ants (B), bark beetles (C), and mole crickets (D) to arachnids such as mites and ticks (E). Cuticle penetration (F) and conidiogenesis from host cadaver (G) are also illustrated. (Images courtesy of D. Boucias and N. O. Keyhani). host range includes insects that act as disease vectors and nuisance pests, crop pests, and even ecologically hazardous, invading pests, with recent studies highlighting the potential of entomopathogenic fungi as agents in combating the spread of malaria by controlling mosquito populations and in protecting agricultural crops from marauding locusts (Inglis et al., 2001; Kirkland et al., 2004b; Scholte et al., 2005; Fan et al., 2012a,b).

$B$. bassiana is a facultative saprophyte that belongs to the Hypocrealean order within the Ascomycota, and has evolved sophisticated mechanisms for penetrating the formidable barrier that constitutes the insect/arthropod exoskeleton or integument (Ferron, 1981; Binnington and Retnakaran, 1991; St Leger, 1991; Clarkson and Charnley, 1996). Interspersed within the cuticle barrier are biochemical components such as toxic lipids and phenols, enzyme inhibitors, proteins, and other defensive compounds that entomopathogens must overcome for successful virulence (Hackman, 1984; Renobales et al., 1991; Anderson et al., 1995). Pathogens must cope with hydrophobic barriers, electrostatic charges, low relative humidity, low or sequestered nutrient levels, endogenous microbial flora, and cross-linked proteins that contribute to a stiff cuticle (St Leger, 1991). Successful pathogenic fungi must also thwart infection-induced responses such as melanization and hemocyte activation (Pendland et al., 1993; Riley, 1997). The overall process of arthropod infection by pathogenic fungi involves many steps (Charnley and St Leger, 1991; Holder and Keyhani, 2005; Lewis et al., 2009; Wanchoo et al., 2009) that include complex systems for (1) finding (likely via passive mechanisms) the appropriate insect host(s), (2) adhering to the exoskeletal substrata, (3) evading host defenses, (4) penetrating and degrading the cuticle, (5) transporting to the cytoplasm and catabolizing necessary nutrients (carbon/nitrogen, external products of the degradation), and (6) dispersing from the catabolized host(s). Infection involves the production of specialized infection structures (appressoria), penetration of the cuticle and surrounding tissues by elongating hyphae (reaching the hemolymph), and the production of single celled hyphal bodies or blastospores within the hemolymph that are able to evade the host immune cells (Hung and Boucias, 1992; Pendland et al., 1993; Kurtti and Keyhani, 2008; Bidochka et al., 2010).

Progress has been made in uncovering some of the molecular and biochemical determinants of B. bassiana virulence. These include descriptions of suites of hydrolases, including proteases, lipases, and phosphatases and the production of numerous toxic metabolites such as beauvericins, oosporein, and oxalic acid. However, little is known concerning the degradation and/or penetration of the initial barrier that must be overcome for successful infection to occur, in particular the hydrocarbons that constitute the insect epicuticle or waxy layer.

\section{BIOSYNTHESIS OF INSECT HYDROCARBONS}

Insect cuticular lipids are comprised of a diverse array of compounds with much variation in content and composition (Blomquist and Dillwith, 1985; Lockey, 1988; Buckner, 1993; Nelson and Blomquist, 1995) (Figure 2). This variation extends to the different life stages (adults, nymphs, larvae) and larval instars of each insect. The composition of surface lipids has profound consequences impacting ecological and behavioral aspects of the insect. Aside from acting as a barrier to desiccation and potential microbial pathogens, surface hydrocarbons contribute to numerous biochemical, physiological, and semiochemical (behavior and signaling) functions. These include roles as species, nest mate, and caste recognition cues and as 


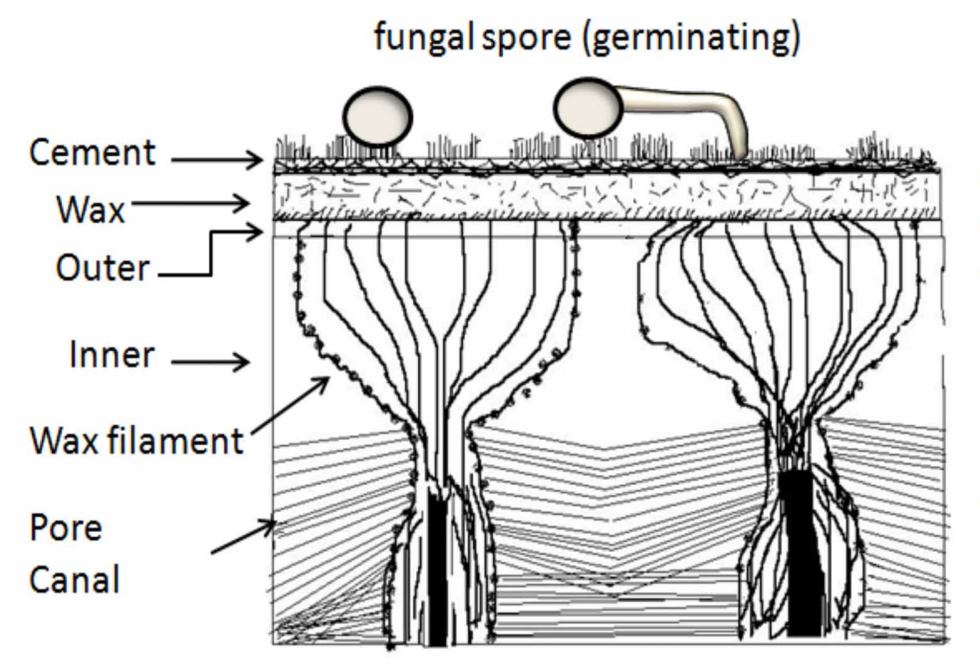

\section{Cuticular hydrocarbons \\ -n-alkanes: $\mathrm{CH}_{3}-\left(\mathrm{CH}_{2}\right)_{n}-\mathrm{CH}_{3}$ -n-alkenes: $\mathrm{CH}_{3}-\mathrm{CH}_{2}=\mathrm{CH}_{2}-\left(\mathrm{CH}_{2}\right)_{n}-\mathrm{CH}_{3}$ -terminally branched alkanes}<smiles>CCC(C)C</smiles>

\section{-internally branched alkanes $\mathrm{CH}_{3}-\mathrm{CH}_{2}-\mathrm{CH}_{-}-\mathrm{CH}_{2}-\mathrm{CH}_{3}$ $\mathrm{CH}_{3}$}

FIGURE 2 | Initial aspects of the fungal-insect interaction: the insect cuticle and its hydrocarbon contents. Image adapted from (Noble-Nesbitt, 1991). The inner, outer, wax, cement, and bloom layers are often considered as the epicuticle, with the pore canals, that transverse the exo-, plus the meso-, and endocuticle portions (not shown in figure) comprising the procuticle. a reservoir for a suite of pheromones responsible for sexual attraction, epideictic (insect display behavior), territorial markers, alarm, recruitment, chemical defense, and thermoregulation (Blomquist et al., 1987; Singer, 1998; Howard and Blomquist, 2005). Additional roles involve predator-prey and parasitoid-host interactions, mimicry and camouflage (Howard, 1993; Dettner and Liepert, 1994). Cuticular lipids include compounds with antifungal activity and components toxic to entomopathogenic fungi (Koidsumi, 1957; Smith and Grula, 1982; Saito and Aoki, 1983; Golebiowski et al., 2008). Hydrocarbons, mainly n-alkanes, alkenes and methyl-branched chains, are the most common epicuticular lipids. In insects, hydrocarbon are synthesized from fatty acids via an elongation-dexcarboxylation pathway which comprises (1) elongation of fatty acyl-CoAs, (2) fatty acids reduction to aldehydes by acyl-CoA reductases, and (3) conversion of fatty aldehydes to alka(e)nes with one less carbon, in an oxidative descarbonylation process catalyzed by cytochrome P450 enzymes (Blomquist et al., 1987, 1993; Nelson, 1993; Qiu et al., 2012). Cuticular hydrocarbons appear to be synthesized in oenocytes, large specialized cells rich in endoplasmic reticulum (ER) and mitochondria. Depending upon the insect species, oenocytes can be found within the epidermis, the peripheral (subcuticular) fat body or the hemocoel (Schal et al., 1998; Bagnères and Blomquist, 2010). Significant aspects of the export and deposition of hydrocarbons on the insect surface remain obscure particularly since it appears that certain parts of the insect do not synthesize hydrocarbons. It is known, however, that some hydrocarbons are transported after synthesis (presumably in the oenocytes) likely via the hemolymph to sites of deposition by reusable lipoproteins known as lipophorins, which shuttle the hydrocarbons among tissues without entering cells (Chino and Kitazawa, 1981; Van Heusden et al., 1991). Several hemolymph lipophorins have been characterized which are capable of binding newly synthesized hydrocarbons from oenocytes to the epicuticle
(Gu et al., 1995; Schal et al., 1998). However, as mentioned, the mechanism of uptake, crossing of the integument, and deposition and/or assembly on the epicuticle remains unknown (Schal et al., 1998; Bagnères and Blomquist, 2010).

\section{DEGRADATION OF INSECT EPICUTICLULAR HYDROCARBONS BY ENTOMOPATHOGENIC FUNGI}

The initial interaction between the fungal infectious propagule, i.e., spores, conidia, or blastospores, and the insect host occurs at the level of the insect epicuticle. It is likely that insect pathogenic microbes such as $B$. bassiana are able to recognize, assimilate and/or alter specific hydrocarbons, which in turn can impact the behavior and ecology of the insect host. Thus, an intriguing corollary to the pathogen-insect interaction is that the action of the fungus via enzymatic modification/degradation of insect cuticular compounds can have a dramatic effect on insect behavior. For instance, by degrading specific pheromones, behaviors such as grooming or nest mate recognition can be modified. Either the host or the pathogen could exploit these effects, i.e., target insects may detect infected individuals as foreign and quarantine/eliminate them (benefiting the host) or induction of behaviors such as enhanced grooming might act as a means for increased dissemination of the pathogen (although grooming typically helps eliminates microbes).

As described above, hydrocarbons, especially n-alkanes, $n$-alkenes, and methyl-branched chains, represent one of the major components of the epicuticle and have been extensively studied (Blomquist and Dillwith, 1985; Blomquist et al., 1987; Lockey, 1988). Insect hosts for examining fungal mediated alkane degradation include the grasshoppers, Schistocerca americana (Drury) and Melanoplus sanguinipes (Fabricius). The alkane component of the surface lipids of S. americana ranges from 25 to $35 \%$ of the total hydrocarbons present, covering chain lengths from $\mathrm{C}_{23}-\mathrm{C}_{35}$. Odd chain hydrocarbons predominate, with the major 
components being $\mathrm{C}_{25}, \mathrm{C}_{27}, \mathrm{C}_{29}, \mathrm{C}_{31}$, and $\mathrm{C}_{33}$ (Lockey and Oraha, 1990; Espelie et al., 1994). Similar values have been reported for the surface lipid composition of M. sanguinipes with $\mathrm{C}_{27}$ and $\mathrm{C}_{29}$ predominating, but also including $\mathrm{C}_{23}$ (Gibbs et al., 1990; Gibbs and Mousseau, 1994). B. bassiana can grow on most of these alkanes as a sole source of carbon.

Alternations in hydrocarbon content during fungal infection of various insects have been noted (Lecuona et al., 1991; Jarrold et al., 2007). Differences in the hydrocarbon content of the waxy layer can have profound effects on fungal pathogenesis. Some hydrocarbons inhibit spore germination, while others stimulate germination and growth (Smith and Grula, 1982; Saito and Aoki, 1983). Cuticular hydrocarbons can also promote (Boucias and Pendland, 1984; Boucias et al., 1988) or inhibit (Lord and Howard, 2004) fungal attachment to cuticle, and specific components may act as chemical inducers for the production of penetrant germ tubes on hosts (Kerwin, 1984; Latge et al., 1987). Spore germination and hyphal growth on insect lipids using pathogenic and non-pathogenic Beauveria strains toward the European common cockchafer (Melolontha melolontha L.) revealed inhibition of growth of the non-pathogenic strain by cuticular pentane extracts derived from the cockchafer, whereas no inhibition of growth of the pathogenic strains was observed (Lecuona et al., 1997). Pentane extracts of two closely related tick species, one highly susceptible to $B$. bassiana (Amblyomma maculatum Koch) and the other somewhat resistant to fungal infection (A. americanum $\mathrm{L}$.), revealed inhibition of fungal germination in the case of A. americanum but good growth on the A. maculatum extracts (Kirkland et al., 2004a). B. bassiana has been shown to utilize several insect hydrocarbons including aliphatic and methyl branched alkanes (Napolitano and Juarez, 1997). $C_{28}$ and $C_{24}$ alkanes were degraded by $B$. bassiana mainly into free fatty acids, phospholipids, and acylglycerols, with alkane grown cells producing $n$-decane as a volatile organic compound as a by-product of the $\beta$-oxidation reactions (Crespo et al., 2000, 2008). Similarly, the major components of the larvae of the blood-sucking bug Triatoma infestans Klug (an important vector of human disease causing microbes) epicuticle includes $\mathrm{C}_{29}, \mathrm{C}_{31}$, and $\mathrm{C}_{33}$ are able to promote B. bassiana growth (Napolitano and Juarez, 1997). Radiolabeled hydrocarbons have been used to investigate the catabolic pathways of alkane degradation in B. bassiana, and these data support a degradative pathway involving $\beta$-oxidation by a cytochrome P450 enzyme system, followed by peroxisome mediated successive transformations to yield the appropriate fatty acyl CoA as further described below (Pedrini et al., 2006, 2007). Alkane growth has been linked to increased virulence, with $B$. bassiana cells grown on alkane containing media displaying a dramatic 2-4-fold increase in mortality against the bean weevil Acanthoscelides obtectus, when compared to cells grown on glucose (Crespo et al., 2002). These data indicate that B. bassiana mediated alkane degradation represents a key metabolic pathway that is linked to the entomopathogenic nature of the fungus.

\section{n-ALKANE ASSIMILATION IN FUNGI}

Little is known concerning how alkanes are taken up and transferred into cells by fungi. Active transport appears to be involved and $n$-alkane uptake experiments performed in Cladosporium resinae in the presence of metabolic uncouplers indicate that the uptake of alkanes in fungi comprises (1) passive adsorption to the outer cell surface where long hair-like structures are formed upon alkane binding, also seen in alkane-grown Candida tropicalis and B. bassiana cells (Kappeli et al., 1984; Juárez et al., 2004) and (2) an energy-requiring transfer of the unmodified alkane into the cytosol (Lindley and Heydeman, 1986). Typically, after binding the cell surface, $n$-alkanes are solubilized in order of increasing molecular weight (Goma et al., 1973; Reddy et al., 1982; Cameotra et al., 1983; Lindley and Heydeman, 1986). Subsequently, these alkanes are shuttled into the cell inside of membrane-bound vesicles likely by a process of pycnocytosis (Meisel et al., 1973; Cooney et al., 1980; Lindley and Heydeman, 1986). Although unclear, the role of these membrane-bound vesicles is thought to provide continuous input of alkanes while avoiding the potential toxicity of insoluble alkanes floating in the cytosol (Lindley and Heydeman, 1986).

Many fungi have developed metabolic systems to assimilate nalkanes as carbon sources via the activities of cytochrome P450 mono-oxygenases (Figure 3) (Lindley, 1995; Van Beilen et al., 2003; Singh, 2006; Rojo, 2010). However, while much is known about these enzymes in $n$-alkane assimilating yeasts, such as Candida maltosa and Yarrowia lipolytica, their orthologs in filamentous fungi have not yet received adequate attention. In yeasts cytochrome P450ALKs (alkanes), belonging to the CYP52 family (Nelson, 2009), are thought to catabolize $n$-alkanes. Where examined, in yeasts, the pathway starts with terminal hydroxylation of alkanes to fatty alcohols by P450ALKs in the ER, and further oxidation to fatty aldehydes either by the fatty alcohol dehydrogenase (FADH) in the ER or by fatty alcohol oxidase (FAOD) in the peroxisome. Whether in the ER or peroxisome, fatty aldehydes are oxidized by fatty aldehyde dehydrogenases (FALDHs) to fatty acids that are further activated by acyl-CoA synthetases (ACS I and/or ACS II). The activated fatty acids are then utilized in membranes or storage lipids, or degraded in the peroxisome via $\beta$-oxidation to yield acetyl-CoA (Fickers et al., 2005). Similarly, in filamentous fungi, the hydroxylation of the terminal methyl group of $n$-alkanes is carried out in the ER by (specific) cytochromes P450s that are coupled to general NADPH-cytochrome P450 reductases. The resultant fatty alcohol can also be catabolized to activate fatty acid in the mitochondrion in addition to ER and peroxisome. The activated fatty acids are catabolized to acetyl-CoA by $\beta$-oxidation in the peroxisome and/or the mitochondrion (Figure 4).

In both yeast and filamentous fungi, although there has been little examination of the central pathways of alkane metabolism, it is considered to involve a predominantly amphibolic tricarboxylic acid cycle with high glyoxylate bypass activity and gluconeogenesis. Such a metabolic pathway results in highly reduced co-enzyme and acetyl-CoA production, with the latter compound feeding anabolic pathways. Alternate pathways include diterminal or subterminal oxidation of alkanes whose products are ultimately assimilated via $\beta$-oxidation reactions, where in the latter case a mixture of secondary alcohols can be formed which are first metabolized to yield the corresponding primary alcohols (which then undergo dehydrogenation) and organic acids (Figure 4). 


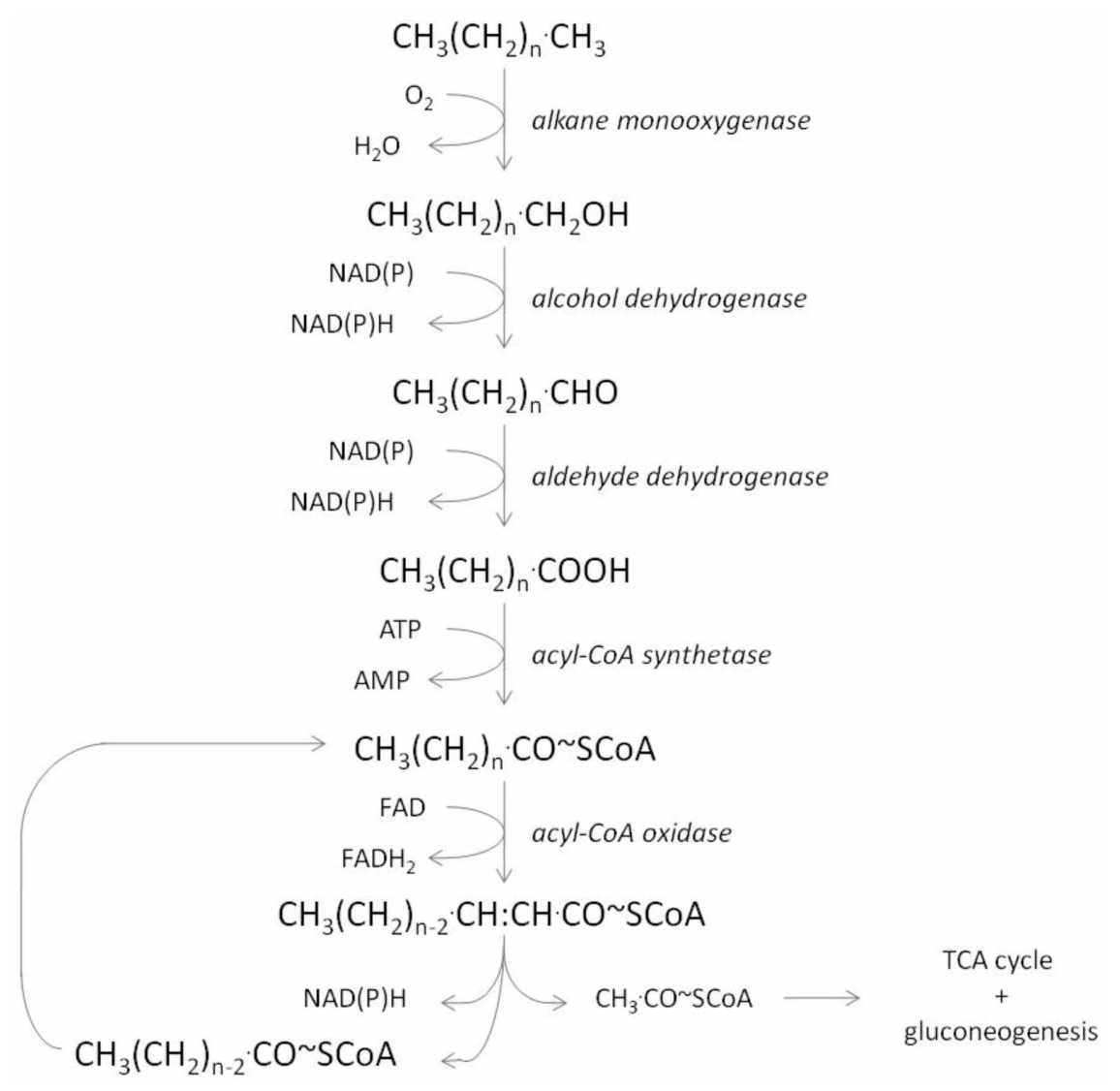

FIGURE 3 | Proposed main catabolic pathway for alkane degradation.

There remain, however, many unanswered biochemical questions regarding $n$-alkane assimilation by fungi.

\section{ALKANE CATABOLIC PATHWAY AND CYTOCHROME P450s IN B. bassiana}

B. bassiana is likely to contain novel enzymes due to the diverse nature and large chain lengths of the hydrocarbon constituents of the insect waxy layer. In the pre-genomic era we identified several genes implicated in alkane degradation in B. bassiana, by exploring our EST dataset (Cho et al., 2006a,b). These included eight cytochrome P450 genes (CYP) encoding enzymes with putative specificity for alkanes (Pedrini et al., 2010), four catalases, and long chain alcohol and aldehyde dehydrogenases (Table 1). Overall, we have identified at least 12 additional $\mathrm{P} 450$ genes (for a total of at least 20 P450 genes in B. bassiana) in EST dataset with substrates specificities for a range of compounds besides alkanes. The recent release of $B$ bassiana complete genome (Xiao et al., 2012) has permitted the extension of this list of genes as follows; 77 CYP genes with families and subfamilies assigned, five catalases and at least 22 alcohol dehydrogenases and 11 aldehyde dehydrogenases.

From genome analyses, fungi have a large diversity in P450 content. Yeasts such as S. cerevisiae, C. albicans, and Y. lipolytica contain 3, 10, and 17 identified P450 ORFs, respectively.
Filamentous fungi such as Neurospora crassa, Magnaporthe grisea, and Fusarium oxysporum, contain 43, 139, and 170 putative P450 enzymes, respectively, and the basidiomycetes, Phanerochaete chrysosporium and the brown rot fungus, Postia placenta contain 145 and 353, P450 ORFs, respectively (Source: Fungal Cytochrome P450 DataBase). Other insect pathogens, such as Metarhizium robertsii and M. acridum, have 123 and 100 CYP genes, respectively (Gao et al., 2011). Thus from genomic analyses, fungi and plants appear to contain the largest complements of CYP genes, probably due to the diversity of both primary and secondary metabolism, and xenobiotic transformation and detoxification pathways.

Within the P450 superfamily, genes are assigned into families and subfamilies based mainly on amino acid sequence identity. Genes are assigned to families when they share greater than $40 \%$ amino acid identity with reference sequences and are assigned to subfamilies when they are more than 55\% identical (Nelson et al., 1996). A higher order for grouping P450 genes, called the clan, has been proposed and applied to studies of P450s from different Kingdoms. The introduction of clan categories attempts to group genes based on robust phylogenetic relationships. Genes within a clan likely diverged from a common ancestor gene (Nelson, 1999) and may share common functions (Nelson, 1998). In fungi, few phylogenetic studies using P450s have been reported. In the 


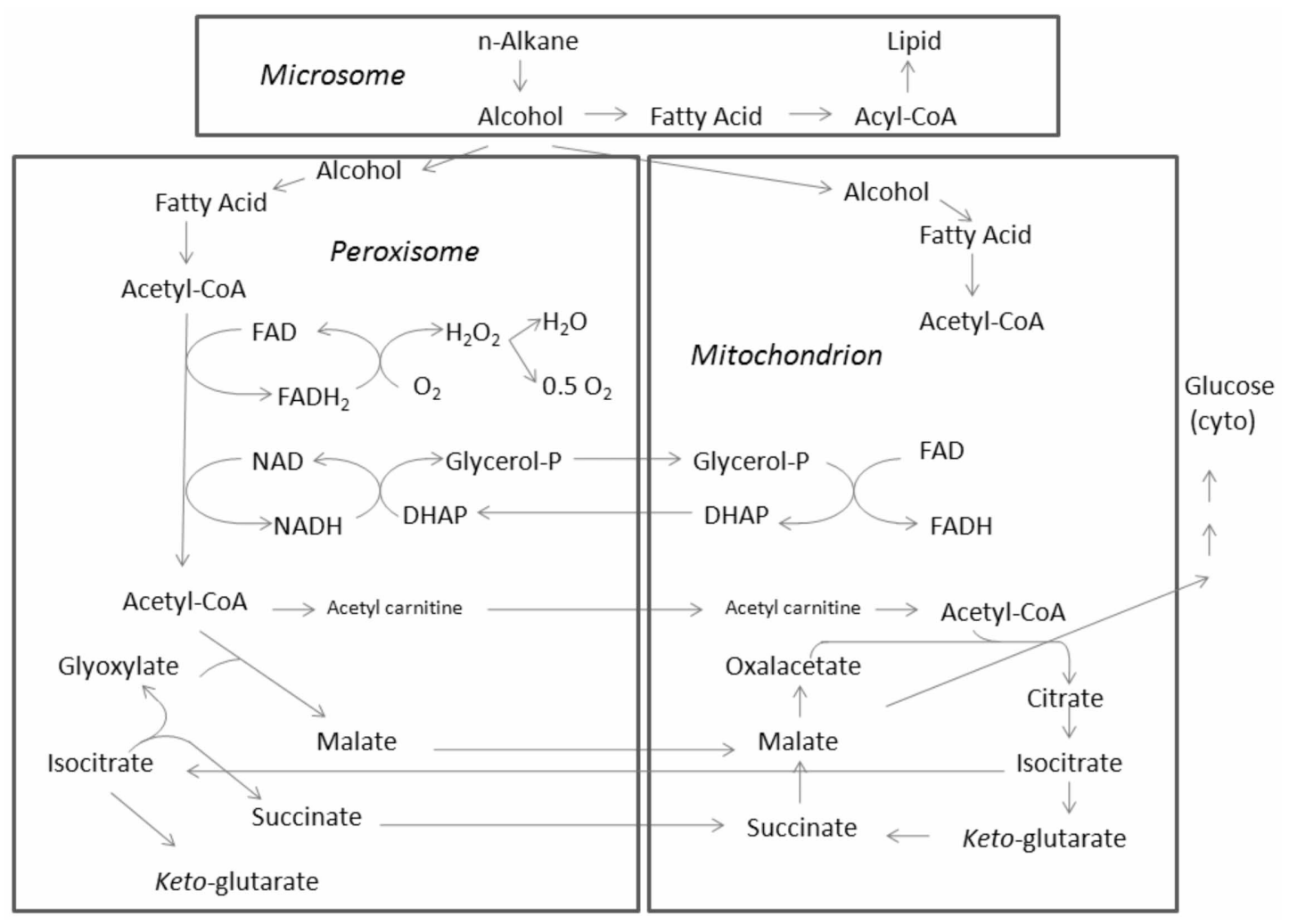

FIGURE 4 | Sub-cellular distribution of hydrocarbon catabolic enzymes.

basidiomycete $P$. chrysosporium, 12 CYP families were classified into 11 clans (Doddapaneni et al., 2005), whereas the sum of the four ascomycetes Aspergillus nidulans, N. crassa, F. graminearum, and $M$. grisea has a total of $376 \mathrm{P} 450$ genes that were assigned to 168 families clustered into 115 clans (in average 42 families and 29 clans per species) (Deng et al., 2007). The availability of the $B$. bassiana genome has contributed to the further annotation of the diversity of fungal P450s; from our analysis at least 15 sequences represent the founding members of a new cytochrome P450 family (20\% of total P450s), and 21 genes (27\%) appear to represent the first members of new subfamilies (Table 2).

Genome mining of $B$. bassiana indicates the presence of two clans that represent $45.5 \%$ of total P450 genes: CYP52 and CYP53 clans (Table 2). The CYP52 family, part of the CYP52 clan, was originally identified in alkane assimilating yeast, and identified to have a role in terminal hydroxylation of $n$-alkanes and fatty acids. This clan includes the highest gene number per family in B. bassiana, with five genes in each of the families CYP52 and CYP584 (the CYP584 family is part of the CYP52 clan). Two genes, belonging to the CYP52 family, have been (partially) characterized in B. bassiana, with evidence that they participate in both hydrocarbon and insect lipid degradation (Pedrini et al., 2010; Zhang et al., 2012). However, BbCYP584Q1 showed little to no induction in any of the alkane growth conditions examined (Pedrini et al., 2010). Other members of this clan (BbCYP539B5 and BbCYP655C1) are induced in the presence of $\mathrm{C}_{16}, \mathrm{C}_{20}, \mathrm{C}_{24}, \mathrm{C}_{28}$, and $T$. infestans lipid extract carbon sources (Pedrini et al., 2010). A phylogenetic analysis of the CYP52 clan revealed that these genes fall into discrete clusters (Figure 5). The significant divergence in amino acid sequence observed may indicate substrates beyond alkanes and/or likely reflects distinct biological roles for subsets of these proteins. The CYP53 family was first described as including benzoate 4-hydroxylases in A. niger and Rhodotorula minuta. B. bassiana has several candidate genes that fall within the CYP53 clan (Figure 6). Amongst these, BbCYP53A26, is induced in the presence of various hydrocarbons and insect lipids (Pedrini et al., 2010), suggesting that this fungus employs a differentiated strategy for hydrocarbon-assimilation using a variety of enzyme classes. However, not all identified cytochromes may be directly involved in lipid assimilation. For example, B. bassiana CYP655C1 (CYP52 clan) expression was strongly induced by hydrocarbons and insect lipids, but it appears to be involved in tenellin synthesis (with aromatic intermediates) (Doddapaneni et al., 2005), indicating that lipid may act as signals for the biosynthesis of select fungal secondary metabolites. In the basidiomycete, $P$. chrysosporium, seven members belonging to the CYP63 family have been identified which all can be classified under the CYP52 clan. All seven genes showed transcriptional induction with alkanes, mono-aromatic and polycyclic aromatic hydrocarbons, and also alkyl-substituted aromatics compounds (Yadav et al., 2006). 
Table 1 | Candidate genes involved in alkane degradation identified in the $B$. bassiana EST dataset.

\begin{tabular}{|c|c|c|c|c|}
\hline Gene (accession No.) & Putative function & $\begin{array}{l}\text { Gene knockout } \\
\text { available? }\end{array}$ & Phenotype & References \\
\hline CYP52(X1) (GU566074) & Lipid oxidation & Yes & $\begin{array}{l}\text { Decreased virulence in insect topical assays/no } \\
\text { effect in intrahemoceol injection assays }\end{array}$ & Zhang et al., 2012 \\
\hline CYP655(C1) (AM409327) & Lipid oxidation & Yes & No phenotype detected thus far & This study \\
\hline $\begin{array}{l}\text { CYP5337(A1) } \\
\text { (GU566075) }\end{array}$ & Lipid oxidation & Yes & No phenotype detected thus far & This study \\
\hline CYP539(B5) (GU566077) & Lipid oxidation & No & - & - \\
\hline CYP617(N1) (GU566078) & Lipid oxidation & Yes & No phenotype detected thus far & This study \\
\hline CYP53(A26) (GU566079) & Lipid oxidation & Yes & No phenotype detected thus far & This study \\
\hline CYP584(Q1) (GU566080) & Lipid oxidation & No & - & - \\
\hline catA (spore-specific) & & Yes & $\begin{array}{l}\text { Decreased virulence, thermotolerance and UV } \\
\text { resistance. Not tested for alkane degradation }\end{array}$ & Wang et al., 2012 \\
\hline catC (cytoplasmic) & $\mathrm{H}_{2} \mathrm{O}_{2}$ scavenging & Yes & Not tested for alkane degradation & Wang et al., 2012 \\
\hline $\begin{array}{l}\text { catD (secreted } \\
\text { peroxidase/catalase) }\end{array}$ & $\mathrm{H}_{2} \mathrm{O}_{2}$ scavenging & Yes & $\begin{array}{l}\text { Decreased virulence and UV resistance. Not } \\
\text { tested for alkane degradation }\end{array}$ & Wang et al., 2012 \\
\hline Acyl CoA oxidase & $\beta$-oxidation pathway & No & N/A & N/A \\
\hline $\begin{array}{l}\text { 3-oxoacyl carrier protein } \\
\text { reductase }\end{array}$ & $\begin{array}{l}\text { Biosurfactants } \\
\text { synthesis/transport }\end{array}$ & No & N/A & N/A \\
\hline ADH-2 FALDH & $\begin{array}{l}\text { Long-chain alcohol and } \\
\text { aldehyde dehydrogenase }\end{array}$ & No & N/A & N/A \\
\hline
\end{tabular}

\section{CYTOCHROME P450 EXPRESSION IN B. bassiana}

The expression pattern of eight B. bassiana cytochrome P450 enzymes has been examined under a variety of conditions (Pedrini et al., 2010). Cells grown in minimal media containing either $\mathrm{C}_{16}, \mathrm{C}_{24}$, or $\mathrm{C}_{28}$ as the sole source of carbon showed significant induction of several of the cytochrome $\mathrm{P} 450$ genes by growth on specific alkanes as compared to glucose grown cells. Of the set of $B$. bassiana cytochrome p450 examined, enzymes belonging to the families CYP52(X1) and CYP617(N1) showed only slight to moderate induction in the alkanes tested. In contrast, BbCYP655(C1) and Bb-CYP52(G11) were induced $>200$-fold in all alkanes tested $\left(\mathrm{C}_{16}, \mathrm{C}_{24}\right.$, and $\left.\mathrm{C}_{28}\right)$, with Bb-CYP655(C1) displaying maximal induction by $\mathrm{C}_{24}$. Bb-CYP5337(A1) showed slight induction when grown on $\mathrm{C}_{16}$ and $\mathrm{C}_{24}$, but $>200$-fold when grown on $\mathrm{C}_{28}$, indicating that it may be important for oxidation of longer chain length alkanes. Bb-CYP53(A26) displayed only minor induction when grown on $\mathrm{C}_{16}$, but $>200$-fold by $\mathrm{C}_{24}$ and $\mathrm{C}_{28}$. Bb-CYP584(Q1) displayed only minor to moderate induction when grown on $\mathrm{C}_{16}$ and $\mathrm{C}_{28}$, but $>200$-fold by $\mathrm{C}_{24}$. These data support a model indicating the presence and importance of a suite of P450 enzymes with overlapping but distinct substrate and expression specificities, particularly since P450s are well-known to be induced by their substrates (Montellano, 2005).

Thus far, the expression patterns of these P450s have only been examined after fungal growth on insect-derived lipids from the blood-sucking bug, T. infestans (Pedrini et al., 2010). Similar to what was observed for the pure alkanes, three distinct induction profiles were noted: Bb-CYP655(C1) and CYP617(N1) were highly induced (>200-fold), Bb-CYP52(X1), CYP5337(A1), and CYP53(A26) were moderately induced ( $>30$-fold), and BbCYP539(B5), CYP52(G1), and CYP584(Q1) displayed low to no induction, i.e., 12 -fold, 4 -fold, and no induction, respectively when grown in $T$. infestans cuticular lipid extracts. Since the content and structure of hydrocarbons and lipids shows considerable variation not only between diverse insect but sometimes between the various life stages of a particular insect, it is intriguing to hypothesize that hydrocarbon assimilating cytochrome P450s may act as partial specificity factors, helping to account for the broad host range of entomopathogenic fungi such as $B$. bassiana. Thus, such an idea would predict that individual members of B. bassiana P450 (lipid assimilating) repertoire would differentially contribute to the pathogenic process depending upon insect target. Further examination of the expression profiles of the P450s after growth on different insects would help shed light on this issue. In addition, knowledge concerning the contributions and/or importance of individual P450s to the ability of the fungus in targeting specific insects could be used to manipulate, i.e., increase, the virulence of the fungus toward those targets, e.g., by increasing the expression levels of critical P450s.

\section{GENETIC DISSECTION OF THE ALKANE PATHWAY: CYTOCHROME P450s}

To date, the role of a single cytochrome P450, Bb-CYP52(X1) has been investigated genetically in B. bassiana (Zhang et al., 2012). A targeted gene knockout mutant of Bb-CYP52(X1) did not display any noticeable growth defects on any substrates tested including 
Table 2 | Cytochrome P450 monooxygenase genes (CYP) in B. bassiana.

\begin{tabular}{|c|c|c|}
\hline CYP clan & CYP family & CYP subfamily \\
\hline CYP 54 & CYP 503 & B1 \\
\hline CYP 504 & CYP 504 & $A 6, B 10, E 1, E 5$ \\
\hline CYP 505 & CYP 505 & A1 (CYPOR), A2, D4 \\
\hline nd & CYP 5060 & $\mathrm{~A} 1$ \\
\hline CYP 531 & CYP 5080 & B3 \\
\hline CYP 56 & CYP 5099 & A1 \\
\hline CYP 51 & CYP 51 & $\mathrm{~F} 1, \mathrm{~F} 2$ \\
\hline CYP 52 & CYP 52 & $\underline{\mathrm{X} 1}, \mathrm{~T} 1, \mathrm{G} 6, \mathrm{G} 8, \underline{\mathrm{G} 11}$ \\
\hline nd & CYP 5202 & A1 \\
\hline CYP 526 & CYP 526 & $\mathrm{H} 1$ \\
\hline nd & CYP 5262 & A3 \\
\hline CYP528 (kr)/53 (dn) & CYP 528 & A4 \\
\hline nd & CYP 5280 & A1P \\
\hline nd & CYP 5282 & $\mathrm{~A} 1$ \\
\hline nd & CYP 5293 & $\mathrm{~A} 1, \mathrm{~A} 2$ \\
\hline$\underline{\text { CYP } 53}$ & $\underline{\text { CYP } 53}$ & $\mathrm{~A} 11, \underline{\mathrm{A} 26}$ \\
\hline$\underline{\text { nd }}$ & $\underline{\text { CYP } 5337}$ & $\underline{\mathrm{A} 1}$ \\
\hline CYP 534 & CYP 534 & $\mathrm{C} 2$ \\
\hline CYP 537 (kr)/53 (dn) & CYP 537 & A4 \\
\hline$\underline{\text { CYP } 52}$ & CYP 539 & $\mathrm{~B} 1, \underline{\mathrm{B} 5}$ \\
\hline CYP 540 & CYP 540 & B16 \\
\hline CYP 505 & CYP 541 & $\mathrm{~A} 2$ \\
\hline CYP 58 (kr)/53 (dn) & CYP 542 & $\mathrm{~B} 1, \mathrm{~B} 2, \mathrm{~B} 3$ \\
\hline CYP $548(\mathrm{kr}) / 53(\mathrm{dn})$ & CYP 548 & A5 \\
\hline CYP 58 & CYP 551 & $\mathrm{C} 1$ \\
\hline CYP 56 & CYP 56 & $\mathrm{C} 1$ \\
\hline CYP 65 (kr)/53 (dn) & CYP 561 & $\mathrm{D} 2 \mathrm{P}$ \\
\hline CYP 507 (kr)/53 (dn) & CYP 570 & $\mathrm{~A} 1, \mathrm{H} 1, \mathrm{E} 2$, \\
\hline CYP 578 & CYP 578 & $\mathrm{~A} 2$ \\
\hline CYP 58 & CYP 58 & A3 \\
\hline CYP 52 & CYP 584 & $\mathrm{D} 4, \mathrm{E} 2, \mathrm{E} 7, \mathrm{G} 1, \mathrm{Q} 1$ \\
\hline CYP 59 & CYP 586 & B1 \\
\hline nd & CYP 6001 & $\mathrm{C} 8$ \\
\hline nd & CYP 6003 & $\mathrm{~A} 1$ \\
\hline nd & CYP 6004 & A2 \\
\hline CYP 61 & CYP 61 & $\mathrm{~A} 1$ \\
\hline$\underline{\text { CYP } 547}$ & $\underline{\text { CYP } 617}$ & $\mathrm{~A} 1, \mathrm{~A} 2, \underline{\mathrm{N} 1}$ \\
\hline CYP 533 & CYP 620 & $\mathrm{C} 2, \mathrm{D} 1$ \\
\hline CYP 533 & CYP 621 & $\mathrm{~A} 2$ \\
\hline CYP 559 & CYP 623 & $\mathrm{C} 1$ \\
\hline CYP 578 (kr)/53 (dn) & CYP 625 & A1 \\
\hline nd $(\mathrm{kr}) / 53(\mathrm{dn})$ & CYP 628 & $\mathrm{~A} 2$ \\
\hline CYP 639 & CYP 639 & A3 \\
\hline CYP 645 & CYP 645 & A1 \\
\hline CYP 65 & CYP 65 & $\mathrm{~A} 1, \mathrm{~T} 7$ \\
\hline$\underline{\text { CYP } 52}$ & CYP 655 & $\underline{\mathrm{C} 1}$ \\
\hline CYP 550 & CYP 660 & A2 \\
\hline CYP 68 & CYP 68 & N1 \\
\hline CYP $58(\mathrm{kr}) / 53$ (dn) & CYP 682 & $\mathrm{H} 1, \mathrm{~N} 1$ \\
\hline
\end{tabular}

(Continued)
Table 2 | Continued

\begin{tabular}{lll}
\hline CYP clan & CYP family & CYP subfamily \\
\hline CYP 58 (kr)/53 (dn) & CYP 684 & A2, B2 \\
& Total & 77 \\
& New CYP family & $15(19.5 \%)$ \\
& New CYP subfamily & $21(27.3 \%)$
\end{tabular}

The genes with experimental evidence of involvement in both hydrocarbon and insect lipid degradation are underlined.

Source: Xiao et al. (2012). Kr, It was generated via the implemented pipeline in the Fungal Cytochrome P450 Database; dn, Nelson's curation; nd, not determined (neither by $\mathrm{kr}$ nor $\mathrm{dn}$ ).

alkanes ranging from $\mathrm{C}_{9}-\mathrm{C}_{28}$, fatty acids, e.g., oleic, linoleic, stearic, palmitic, myristic, and lauric acids, or in media containing olive oil. Intriguingly, neither wild type nor the mutant strain was able to grow on pelargonic acid. A grasshopper wing assay in which fungal spores are deposited onto dissected wings and germination/fungal growth was measured, however, revealed a difference between the wild type and $\triangle \mathrm{Bb}$-CYP52(X1) strains. Germination of the mutant strain on the grasshopper wings was $50 \%$ lower than the wild type or complemented mutant strains, the latter representing a mutant strain in which the wild type gene was retransformed into the fungus under control of its endogenous promoter. Perhaps the most interesting results dealt with the virulence of the mutant strain in insect bioassays. As previously mentioned, B. bassiana infects target host via (random) attachment to the cuticle, followed by germination, hyphal growth along the surface, and penetration through the cuticle into the insect hemocoel. Topical application of fungal conidia (spores) represents that "natural" route of infection, and experiments performed using the Greater Waxmoth, Galleria mellonella, indicated a $25-50 \%$ reduction in virulence (time to kill, $\mathrm{LT}_{50}$ value) in the $\triangle \mathrm{Bb}$-CYP52(X1) strain as compared to the wild type and complemented strains. Cuticle penetration can be bypassed, however, by directly injecting the fungal cells into the insect hemoceol. In such experiments, i.e., intrahemoceol injection assays, the mutant strain was as virulent as the wild type parent. These data support a hypothesis that certain cytochrome P450 enzymes are important for cuticle penetration events, presumably via assimilation or detoxification of cuticular substrate for the enzyme, but that these P450s are not required for post-penetration events once the cuticle has been breached. An important piece of the puzzle, however, remains obscure, namely, since P450s are ER-derived membrane bound proteins, how are their (cuticular) substrates accessed and/or transported to the proteins?

We have also constructed targeted gene knockouts of the six out of eight of the other identified cytochrome P450 enzymes implicated in insect hydrocarbon degradation (Table 1). However, to date, no phenotype with respect to growth or germination on lipids or virulence has been noted for any of these mutants (data not shown). These results may not be too surprising for several reasons. First, due to the potential redundancy and/or (partial) overlapping substrates specificities of these enzymes single gene knockout like we have constructed may not display any noticeable phenotypes. This has been also 


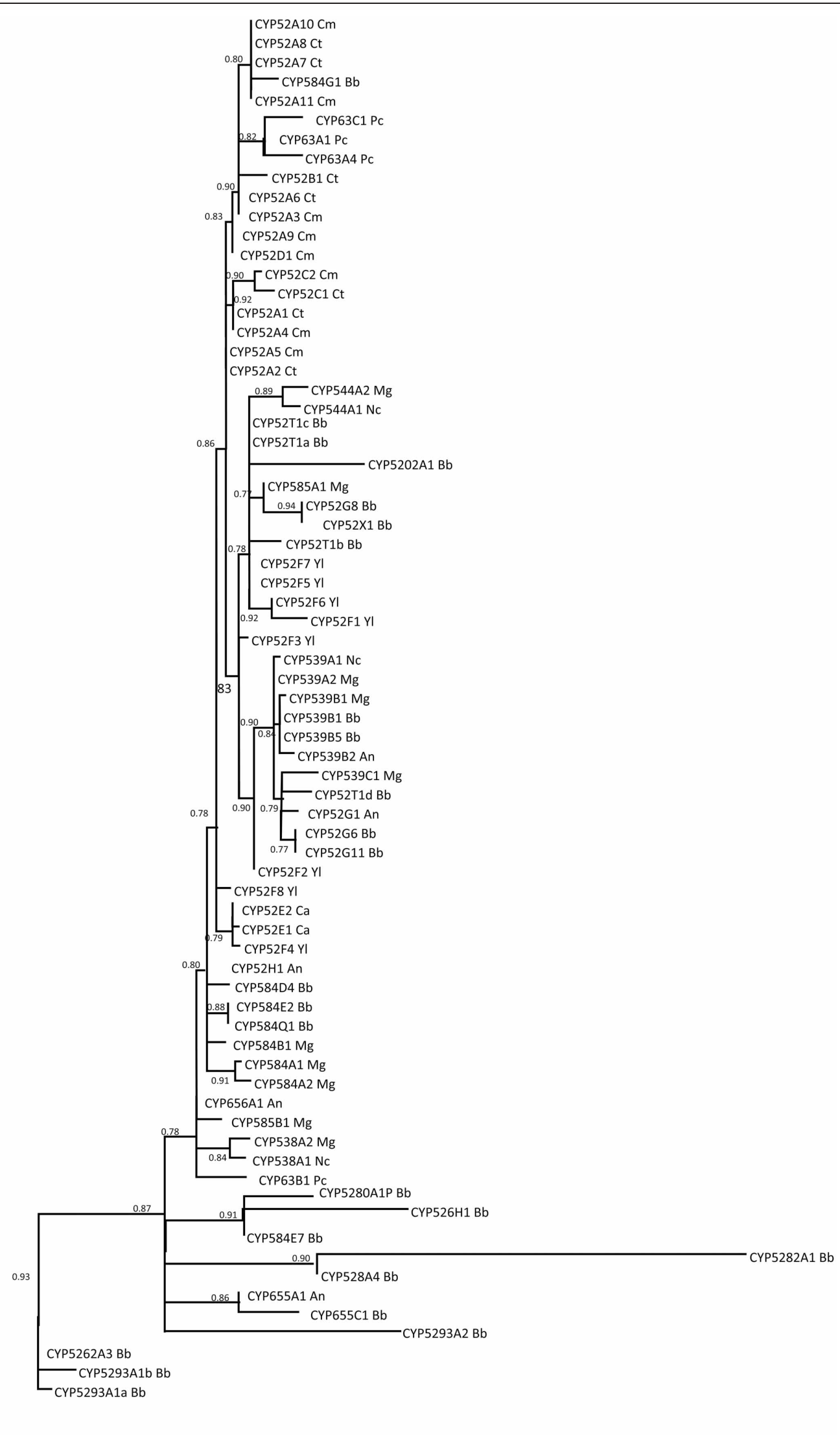

FIGURE 5 | Continued 
FIGURE 5 | Maximum likelihood phylogenetic tree of clan 52 cytochrome P450s. The putative conserved domains for each protein were picked up from the conserved domain database (CDD) (Marchler-Bauer et al., 2011), and aligned using MUSCLE. The multiple sequence alignment was cured with Gblocks. PhylML was used to build the tree. All the analyses were performed at the online platform Phylogeny.fr (Dereeper et al., 2008, 2010). Numbers at nodes indicate $\mathrm{SH}$-like branch support. Scale bar indicates number of amino acid substitutions per site. Amino acid substitution model John Taylor Thornton (JTT).

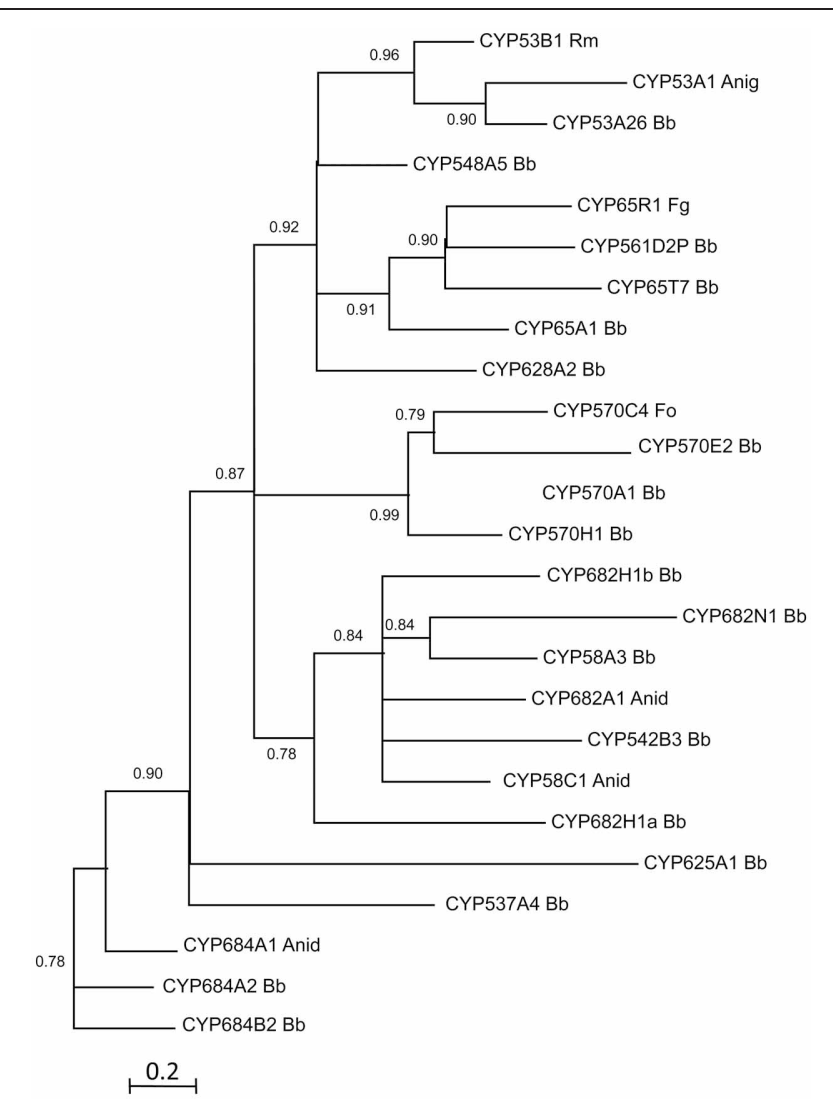

FIGURE 6 | Maximum likelihood phylogenetic tree of clan 53 cytochrome P450s.

observed in Y. lipolytica, where the abundance of paralog genes encoding for alkane degradation proteins, makes it difficult to unravel the function and the physiological substrate(s) of individual alkane degradation proteins (Takai et al., 2012). Second, the virulence of these strains have only been examined with respect to a single insect target ( $G$. mellonella), it is possible that some of these enzymes may have substrates found on other targets not present on G. mellonella. Thus, assaying a diversity of target insects may reveal differential contributions of various $\mathrm{P} 450$ s to the pathogenic process toward specific insects. If properly demonstrated, this would support the idea that P450s can act as insect target specificity factors, contributing to the broad host range nature of B. bassiana.

\section{BIOCHEMICAL CHARACTERIZATION OF B. bassiana CYTOCHROME P450s}

B. bassiana CYP52(X1) has been expressed in a yeast (Saccharomyces cerevisiae) heterologous expression system and its activity examined in yeast-derived microsomal extracts (Zhang et al., 2012). This yeast system has been optimized for expression of cytochrome P450s and contains elevated amounts of the needed companion reductase for activity (Pompon et al., 1996). Intriguingly, although a low spin heme spectrum was detected in yeast microsomes isolated from expression-induced cells harboring the Bbcyp52x1 plasmid construct, no CO difference spectral shift, a tell-tale biophysical signal for cytochrome P450 content, was observed. The (ER-derived) microsomes, however, displayed NADPH-dependent oxidation of a number of substrates under conditions in which no activity was detected in control microsomes derived from wild type yeast cells or cells transformed with an empty vector. Use of radiolabeled lauric and oleic acids followed by GC/MS analysis confirmed CYP52X1 mediated NADPH-dependent regioselective addition of a terminal hydroxyl to both substrates. TLC analysis of reaction products using a variety of other fatty acid substrates revealed that CYP52X1 displayed highest activity against C12:0, C14:0, and epoxy stearic acid, 4-8-fold lower activity against C16:0, C18:1, and C18:2, and little to no activity toward C9:0 and C18:0 (Zhang et al., 2012).

Additional B. bassiana proteins, namely, CYP5337A1, CYP617N1, CYP53A26, and CYP584Q1 have also been expressed in the same yeast system. These constructs contained N-terminal his-tags which have been used for partial purification using immobilized metal ion chromatography ( $\mathrm{Ni}^{2+}$ IMAC) (Figure 7). Of the proteins examined thus far, only CYP53A26 showed a CO spectrum corresponding to the oxidized protein, including a peak at $426 \mathrm{~nm}$ and a small shoulder at $450 \mathrm{~nm}$ (Figure 7). The rest of the proteins showed no CO difference spectral shift when dithionite was added (data not shown). Poor or atypical CO spectra have been reported for a number of cytochrome P450s including some plant P450s that have weak affinity for CO (Lau et al., 1993), and P450 19A1 (human aromatase) which does not bind CO (Harada, 1998; Gartner et al., 2001). Our data suggest that the number of P450s with atypical CO spectra is greater than what is currently thought.

\section{FATTY ALCOHOL AND ALDEHYDE DEHYDROGENASES}

Upon terminal hydroxylation of alkanes to fatty alcohols by P450ALKs, fatty alcohol and aldehyde dehydrogenases (FADHs and FALDHs) oxidize the fatty alcohols to fatty aldehydes and fatty acid, respectively. There have been few reports examining fungal very long chain alcohol and aldehyde dehydrogenases, and little is known concerning their potential role in the oxidation of the fatty alcohol products of P450 activity. Dehydrogenases, however, are considered to yield the fatty acids that feed into the $\beta$-oxidation pathway. Fatty alcohol dehydrogenases (FADHs) are mainly linked to the biosynthesis of mannitol, an important intracellular carbohydrate factor that participates in stress tolerance 
A

\section{lane $1 \quad$ lane $2 \quad$ lane $3 \quad$ lane $4 \quad$ lane 5}
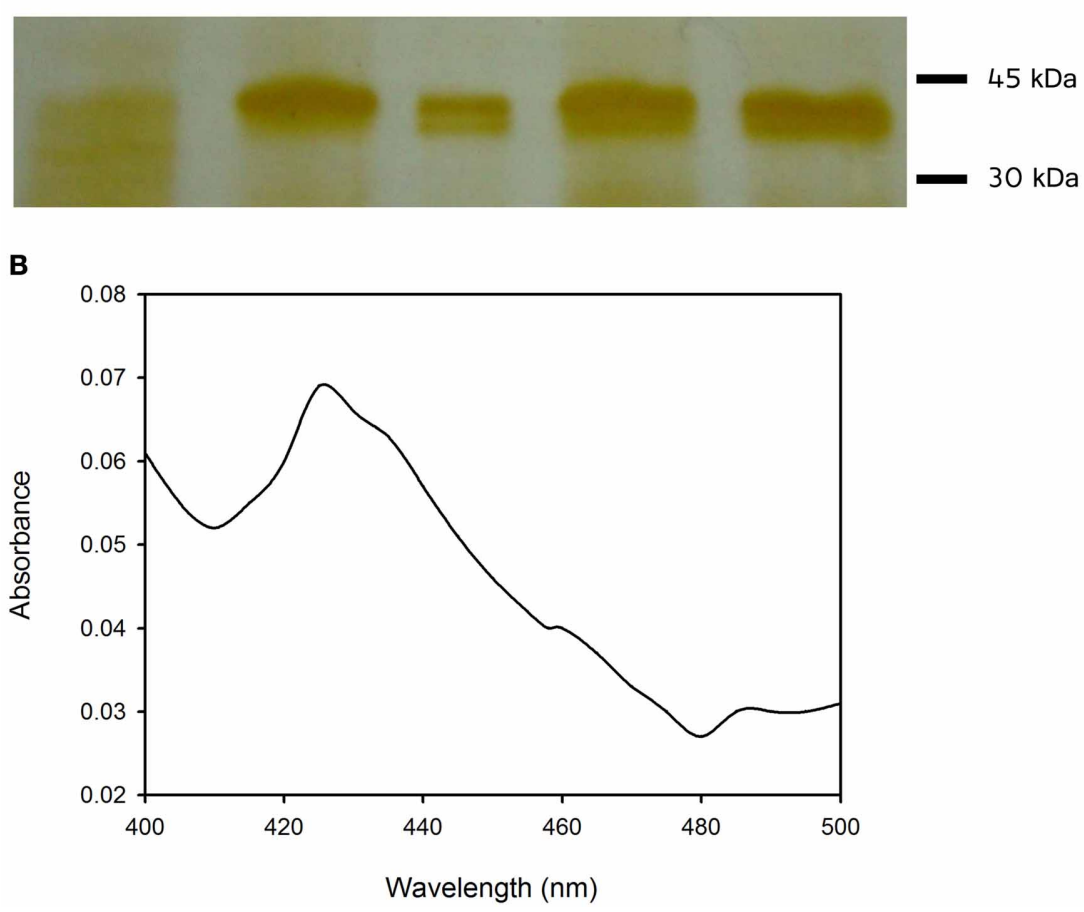

FIGURE 7 | (A) SDS-PAGE of partial purified proteins using immobilized metal ion chromatography $\left(\mathrm{Ni}^{2+} \mathrm{IMAC}\right)$ : vector without insert (lane 1), CYP52X1 (lane 2), CYP5337A1 (lane 3), CYP617N1 (lane 4), and CYP53A26 (lane 5). Examined proteins were expressed in the yeast Saccharomyces cerevisiae WAT11. The cells were transformed with the lithium acetate method (lto et al., 1983) for microsome isolation purposes. Proteins were solubilized with $10 \% \mathrm{w} / \mathrm{v}$ sodium cholate and loaded onto the column. (B) CO difference spectrum of CYP53A26: Sodium dithionite and CO were added to the purified protein, and absorbance between 400 and $500 \mathrm{~nm}$ was measured. and has even been linked to virulence in certain fungal pathogens. M. anisopliae has 17 zinc-containing alcohol dehydrogenases (Gao et al., 2011). FALDHs, responsible for the oxidation of various aldehydes to their corresponding carboxylic acids are widely distributed in filamentous fungi. Although little empirical data is currently available, it is postulated that in entomopathogenic fungi specific FALDHs may exist with substrate specificity for the aldehydes present or generated during cuticular hydrocarbon assimilation. Two M. anisopliae FALDHs have thus far been examined in relation with cuticle degradation, and these have been shown to be up-regulated in when the fungus is grown in the presence of insect cuticles as compared to growth in sugarrich media (Freimoser et al., 2005). It is likely therefore that the observed induction of these genes in the presence of insect cuticle is a consequence of the availability of aldehydes resulting from the oxidation of cuticular hydrocarbons.

In the Aspergillus nidulans ethanol utilization pathway, FALDH and FADH are co-regulated, at the transcription level, via the alc regulon (Flipphi et al., 2001). Aside from ethanol and acetaldehyde, other inducers of the alc system including amino acids and other aliphatic alcohols have been identified. However, it is thought that the real physiological inducers are aldehydes, and that the other examined compounds are first converted to their corresponding aldehydes in order to act as inducers (Flipphi et al.,
2001). Analysis of the promoter region of the FALDH ald1 of the mycorrhizal fungus Tricholoma vaccinum revealed the presence of five putative stress response elements (STREs) (Asiimwe et al., 2012). These elements have also been detected in the promoters of several B. bassiana CYP genes (Pedrini et al., 2010), suggesting common induction/regulatory compounds and pathways function to co-regulate FALDH, FADH, and CYP activities. It should be noted that alternative pathways also exist; the alkaneassimilating yeast $C$. maltosa is able to catalyze the production of a cascade of mono-oxidation products followed by di-terminal oxidation of substrates to yield $\alpha-\omega$ acids. These reactions can be catalyzed by a single P450 enzyme and include both alcohol and aldehyde intermediates but do not use the corresponding dehydrogenases (Scheller et al., 1998). Although no evidence exists for such pathways in B. bassiana, at this time they cannot be excluded.

Feeding of hydrocarbon assimilation products into central metabolic pathways (Figure 4) may also contribute to the $B$. bassiana pathogenic lifecycle. Isocitrate lyase (ICL) and malate synthase (MLS) are not only up-regulated during growth on two-carbon compounds including acetate and ethanol, but also during growth in insect hemoplymph (Padilla-Guerrero et al., 2011). In M. anisopliae, $i c l$ is up-regulated during the initial infection stage of appressoria formation as well as during late host growth events when the fungi are engulfed by insect heamocytes, 
highlighting the contribution of the glyoxylate cycle in pathogenesis (Padilla-Guerrero et al., 2011). Production of metabolic acids by entomopathogenic fungi, potentially resulting from cuticular hydrocarbon recognition and assimilation cues, can also directly participate in insect virulence; and citrate, formate, and oxalate have been shown to contribute to B. bassiana virulence (Bidochka and Khachatourians, 1991; Kirkland et al., 2005). Oxalate production in particular contributes to pathogenesis via acidification of host tissues, sequestration of metal ion such as calcium, magnesium, manganese, and iron and could inhibit or disrupt host defense responses (Kirkland et al., 2005).

\section{CATALASES}

Fatty acids are completely catabolized through $\beta$-oxidation. Peroxisomal proliferation together with a marked induction of the $\beta$-oxidation system has been related to alkane-growth adaptation in B. bassiana (Crespo et al., 2000). The typical peroxisomal marker enzyme is catalase, a hemoprotein that decomposes excess $\mathrm{H}_{2} \mathrm{O}_{2}$ produced by $\beta$-oxidation. Peroxisomal catalase induction was observed in alkane-grown B. bassiana, a high increment in the catalase activity (14-fold) was measured in these fungi compared with control cultures grown in complete medium (Pedrini et al., 2006). Catalase activity was also detected in the cytosolic fraction of B. bassiana, although this isoform was not induced in the same culture condition (Pedrini et al., 2006). Catalase induction was proposed as a simple biochemical marker to follow the course of fungal growth adaptation in insect-like hydrocarbons and was correlated with enhance virulence parameters (i.e., lower $\mathrm{LC}_{50}$ and/or $\mathrm{LT}_{50}$ ) (Crespo et al., 2002; Pedrini et al., 2007, 2009).

The catalase family of $B$. bassiana consists of at least five genes designed as; catA (spore-specific), catB (secreted), catP (peroxisomal), catC (cytoplasmic), and catD (secreted peroxidase/catalase). The functions of these genes and their protein products have been studied via generation of single targeted gene disruption mutant strains (Wang et al., 2012). CatB appeared to account for the predominant catalase activity produced by the fungus with $\Delta$ catB mutants displaying $\sim 90 \%$ decrease in total catalase activity, however $\Delta$ catP mutants were reported to results in $\sim 55 \%$ decrease in total catalase activity, suggesting negative pleiotropic effects between certain catalases. Intriguingly, $\Delta$ cat $B$ (and $\Delta \mathrm{catC}$ ) mutants displayed only minor phenotypic effects, which the authors explain by the observation of up-regulation of the other catalases in these mutants and hence potential functional redundancy. If correct, it is unclear, however, how this would explain the low ( $\sim 10 \%$ of wild-type) activity seen in the $\Delta$ catB mutant. $\Delta$ catA strains were more theromosensitive than the wild type parent, showed a $\sim 50 \%$ decrease in UV-B resistance, decreased virulence in insect bioassays, and conidial sensitivity to $\mathrm{H}_{2} \mathrm{O}_{2}$ although colony growth in the presence of $\mathrm{H}_{2} \mathrm{O}_{2}$ was essentially unaffected. $\Delta$ catD strains were unaffected in thermal stability and oxidative stress in general, but did display reduced UV-B tolerance and virulence in insect bioassays. Deletion of the peroxisomal catalase (catP), the enzyme most likely to be involved in hydrocarbon assimilation pathways, resulted in increased sensitivity to oxidative stress both on the conidial germination level and during colony (vegetative) growth. $\Delta$ catP mutants were essentially unaffected in thermal sensitivity and UV-B tolerance, but displayed $\sim 50 \%$ decrease in virulence $\left(\mathrm{LT}_{50}\right)$ indicating that it is an important enzyme involved in the pathogenic process (Wang et al., 2012). Although alkane and hydrocarbon assimilation in the catP (or other catalase) mutants has not yet been examined, these data suggest that peroxisomal catalases might be crucial factors for adaptation to oxidative stress generated during fungal growth on insect alkanes and other hydrocarbons.

\section{INSECT CUTICULAR HYDROCARBONS SYNTHESIS AND FUNGAL HYDROCARBON ASSIMILATION—AN EXAMPLE OF "RED OUEEN" CO-EVOLUTION?}

The co-evolutionary arms race between a pathogen and its target host has been referred to as the "Red-Queen Hypothesis," and is taken from Lewis Carroll's Through the Looking Glass, where in the Red Queen's race "it takes all the running you can do, to keep in the same place" (Van Valen, 1973). The hypothesis is that target hosts evolve mechanisms for resistance against pathogens, and that pathogens, in turn, evolve mechanisms for surmounting the evolving host defenses. Could insect cuticular hydrocarbon synthesis be under a Red Queen selection mechanism? It is undoubtable that the insect epicuticle layer, with its complexity of hydrocarbons serves as a means for protection against abiotic stress, e.g., desiccation, heat, and even potentially UV irradiation, and that this layer serves as a platform for semiochemicals involved in insect communication and signaling. It is also clear that many of the hydrocarbons present in the epicuticle have antimicrobial properties and suppress the growth of microbes. Antimicrobial mechanisms may be passive in that these hydrocarbons are poor substrates for most microbes and that they can effectively sequester nutrients from scavenging and/or attacking parasites. However, there is ample evidence for the existence of chemically diverse species-specific antimicrobial compounds targeted for secretion to the insect epicuticle. Both such molecules must be overcome for successful pathogenesis to occur. Specific antimicrobial compounds would require detoxification and/or remediation that occur via enzymatic inactivation and/or efflux or sequestration of such molecules via multidrug-efflux systems. In this respects $B$. bassiana displays a high level of resistance to many antifungal compounds and genomic analyses has revealed a large set of detoxifying enzymes as well as efflux transporters. Insect epicuticles, however, often contain significant amounts of long chain hydrocarbons, whose purpose regarding abiotic stress and/or semiochemicals potential are obscure. However, long(er) chain hydrocarbons become increasingly difficult for microbes to assimilate and can directly inhibit the growth of many bacteria and fungi. As elongation reactions in insect hydrocarbon biosynthesis typically add two-carbons to the growing chain, from a biochemical and physiological stand-point, increasing chain length and secreting/transporting the products to the epicuticle represents a facile mechanism to thwart the growth of potential pathogens. Successful pathogens, in turn must develop mechanisms for bypassing and/or degrading the ever-growing hydrocarbon chain lengths. In short, could fungal pathogens help explain the diversity and chain length of insect hydrocarbons on the one hand, and the evolution of specific enzymes (cytochrome P450s) and pathways to assimilate these lipids on the other? It should be noted that to date, there is little empirical evidence 
to support this idea, however, such a hypothesis does make certain predictions and can help explain certain phenomena. First, one would predict that insects that make longer chain hydrocarbons that $B$. bassiana cannot assimilate would be more resistant to fungal infection or vice versa that insects which display resistance to $B$. bassiana do so because of epicuticular lipid content, in particular by synthesizing longer and/or branched-chain hydrocarbons. Second, epicuticular hydrocarbon content may explain strain variation and sub-specificity seen between different fungal isolates. Finally, it is known that even amongst some (B. bassiana) susceptible insect species certain developmental stages (instars) are more resistant than others. Since epicuticular hydrocarbons are known to vary between such developmental stages, one could predict that these differences may help account for the variation in pathogen susceptibility observed.

\section{CONCLUDING REMARKS}

The lipid-rich insect epicuticle represents the first barrier against, and mediates the initial interaction with, microbial pathogens. Targeting of this layer by the entomopathogenic fungus Beauveria bassiana occurs within the context of a host-pathogen interaction. Aspects of the biochemical basis for fungal mediated hydrocarbon oxidation and assimilation have been uncovered. Genomic, genetic, and biochemical data indicate that the fungus contains a repertoire of cytochrome P450 enzymes, likely with over-lapping specificities, along with attendant downstream pathways, that act to assimilate insect hydrocarbons. There remain, however, many unanswered questions and significant aspects of the fungal-epicuticle interaction remains obscure. The substrate specificities of only one B. bassiana cytochrome P450 has been examined, and questions concerning the uptake and transport of hydrocarbons into the fungus have yet to be adequately addressed. The idea that epicuticular hydrocarbon synthesis and fungal assimilation of these compounds may represent a co-evolutionary race needs empirical support. Further research aimed toward examining these and other questions can yield novel insights into the biochemistry of hydrocarbon degradation as well as into the ecology and evolution of the interaction between fungal entomopathogens and their insect hosts, and can impact practical applications of fungi in biological control of insects and/or exploitation of the fungal hydrocarbon pathways in biotechnological applications.

\section{MATERIALS AND METHODS CHEMICAL REAGENTS AND CULTIVATION OF FUNGI}

Beauveria bassiana (ATCC 90517) was routinely grown on potato dextrose agar (PDA) or Czapek-Dox plates. Plates were incubated at $26^{\circ} \mathrm{C}$ for $10-15$ days and aerial conidia were harvested by flooding the plate with sterile distilled water. Conidial suspensions were filtered through a single layer of Miracloth and final spore concentrations were determined by direct count using a hemocytometer. The $S$. cereviseae WAT11 strain was used for heterologous expression of $B$. bassiana cytochrome P450s. Yeast cells were grown at $30^{\circ} \mathrm{C}$ in Difco Yeast Nitrogen Base medium without amino acids (YNB-aa, $6.7 \mathrm{~g} / \mathrm{L}$ ) containing glucose or galactose at $2 \%(\mathrm{w} / \mathrm{v})$ with supplements as indicated. Chemical reagents were obtained from either Fischer
Scientific or Sigma-Aldrich chemicals unless otherwise noted. Phosphinothricin was purchased from Gold Biotech or purified in the lab from the herbicide Finale (AgrEvo, Montvale, NJ) as described (Metzenberg et al., 2000).

\section{NUCLEIC ACID MANIPULATIONS AND CONSTRUCTION OF B. bassiana CYTOCHROME P450 KNOCKOUT STRAINS}

All primer sequences for the nucleic acid manipulations, RTPCR, Southern blot probe generation, and yeast expression vector construction are listed in Table 3. To generate the vector for construction of the cytochrome P450 knockout strains in B. bassiana via homologous recombination, fragments for each gene (see Table 1 for list of P450s and accession numbers) were amplified from genomic DNA using the primer pairs as listed in Table 3. PCR products was cloned into the pCR2.1-TOPO blunt-end vector (Invitrogen) generating pTOPO-Bbcyp450xxx clones for each gene. Long-range deletion inverse PCR using the primer pair for each gene (Table 3) were then used to produce linear fragments lacking 50-200 bp of internal sequence for each gene using the respective pTOPO-Bbcyp450 plasmid of each gene as template. The generated linear DNA was then blunt-end ligated to a PCR product corresponding to the herbicide resistance gene (bar) cassette amplified from pBAR-GPE (Sweigard et al., 1997) using primer pair $\mathrm{pBARF}$ and $\mathrm{pBARR}$. The integrity of each resultant gene replacement plasmid designated as $\mathrm{pKO}-B b c y p 450 x \times x$, was confirmed by PCR and sequencing. Preparation of competent cells, transformation, and screening of recombinant clones was performed as described using a PEG-LiAc mediated protocol (Zhang et al., 2010; Fan et al., 2011). The transformation mixture $(0.25-0.5 \mathrm{ml})$ was plated onto Czapek-Dox medium containing $200 \mathrm{mg} / \mathrm{ml}$ phosphinothricin, $0.01 \%$ bromocresol purple, $\mathrm{pH} 6.3$, in $150 \mathrm{~mm}$ diameter Petri dishes overlaid with a sheet of sterilized cellophane. Genomic DNA was isolated as described (Liu et al., 2000). Putative B. bassiana gene knockout clones were screened and verified by PCR analysis using primers designed to each Bbcyp450 gene (Table 3). PCR reactions were performed using the following protocol: $95^{\circ} \mathrm{C}$ for $3 \mathrm{~min}$, followed by 35 cycles of denaturation at $95^{\circ} \mathrm{C}$ for $30 \mathrm{~s}$, annealing at $56^{\circ} \mathrm{C}$ for $30 \mathrm{~s}$, and extension at $72^{\circ} \mathrm{C}$ for $1 \mathrm{~min}$. Transformants were confirmed by PCR and RT-PCR using primers as listed in Table 3.

\section{GROWTH AND GRASSHOPPER WING GERMINATION ASSAYS}

Fungal growth experiments of various hydrocarbons were performed as follows; fungal spores were harvested from PDA plates directly into sterile distilled water and were washed twice with the same solution; the suspension was then adjusted to $10^{7}-10^{8}$ conidia $\mathrm{ml}^{-1}$ after counting using a hemocytometer. Spore suspensions $(5-10 \mu \mathrm{l})$ were then placed into the middle of microtiter agar plates (24- or 48-well). For 24-well plates, each well contained $1 \mathrm{ml} \mathrm{MM}$ in Noble agar overlaid with the desired alkane $(0.1 \mathrm{ml}$ of $\mathrm{a} 10 \%$ hydrocarbon stock solution in hexane) as a carbon source. Substrates tested included the following alkanes $(0.1 \%) ; \mathrm{C}_{9}, \mathrm{C}_{10}, \mathrm{C}_{12}, \mathrm{C}_{14}, \mathrm{C}_{16}, \mathrm{C}_{18}, \mathrm{C}_{24}$, and $\mathrm{C}_{28}$. Grasshopper wings sterilized using $37 \% \mathrm{H}_{2} \mathrm{O}_{2}$ were immersed in a conidial suspension in water at a concentration of $1 \times 10^{6}$ spores $/ \mathrm{ml}$ for $20 \mathrm{~s}$, and placed on $0.7 \%$ water agar. After incubation for $18 \mathrm{~h}$, the germinated conidia were counted under a light microscope. 
Table 3 | Primers used in this study.

\begin{tabular}{|c|c|c|}
\hline Name & Sequence $\left(5^{\prime}\right.$ to $\left.3^{\prime}\right)$ & Use \\
\hline pBARF & GTCGACAGAAGATGATATTGAAGG & $\begin{array}{l}\text { KO strain } \\
\text { construction }\end{array}$ \\
\hline pBARR & TCATCAGATCTCGGTGACGGGCAGG & $\begin{array}{l}\text { KO strain } \\
\text { construction }\end{array}$ \\
\hline \multicolumn{3}{|c|}{ CYP5337A1 KNOCKOUT } \\
\hline P4F & GTGTGCGTGATCCAGAGCTCTGC & $\begin{array}{l}\text { KO strain } \\
\text { construction }\end{array}$ \\
\hline P4R & GCACCAAGTTTCGAGACTGGGACAT & $\begin{array}{l}\text { KO strain } \\
\text { construction }\end{array}$ \\
\hline P4KOF & ACTTACGACCTATGCAGATGCGC & $\begin{array}{l}\text { KO strain } \\
\text { construction }\end{array}$ \\
\hline P4KOR & GTTGGCTTGTATGGGATTACGCC & $\begin{array}{l}\text { KO strain } \\
\text { construction }\end{array}$ \\
\hline P4RTPCRF & CACATTGTTGTACGCGGTACTTTGC & KO screening \\
\hline P4RTPCRR & TATGGTCCGGATGCAATGGAGTGG & KO screening \\
\hline \multicolumn{3}{|c|}{ CYP52G11 KNOCKOUT } \\
\hline P5F & CGCTCACTGCTATCCTCATCGGC & $\begin{array}{l}\text { KO strain } \\
\text { construction }\end{array}$ \\
\hline P5R & CAGAACAGCGATAACGTGACGAGCT & $\begin{array}{l}\text { KO strain } \\
\text { construction }\end{array}$ \\
\hline P5KOF & CAAGGGCGGCTGGGAATATCTC & $\begin{array}{l}\text { KO strain } \\
\text { construction }\end{array}$ \\
\hline P5KOR & TTCTCGTAGCCGCCAAAGGTCT & $\begin{array}{l}\text { KO strain } \\
\text { construction }\end{array}$ \\
\hline P5RTPCRF & СTCСTCAACGTCCTCCTCGCCGG & KO screening \\
\hline P5RTPCRR & GAGGAGTCGGGCGAGGACGTAAC & KO screening \\
\hline \multicolumn{3}{|c|}{ CYP617N1 KNOCKOUT } \\
\hline P7F & GAAAGCCCCAACGAAGGCCTGAT & $\begin{array}{l}\text { KO strain } \\
\text { construction }\end{array}$ \\
\hline P7R & GAAGTTGCCCGGTCCCTTGTCAA & $\begin{array}{l}\text { KO strain } \\
\text { construction }\end{array}$ \\
\hline P7KOF & GGACAAGTCTCTTCTTGACGAAAGCA & $\begin{array}{l}\text { KO strain } \\
\text { construction }\end{array}$ \\
\hline P7KOR & ATTGGTCGCATTCTTGCCGCC & $\begin{array}{l}\text { KO strain } \\
\text { construction }\end{array}$ \\
\hline P7RTPCRF & TGGGATTGGTGCCGTGGGCAA & KO screening \\
\hline P7RTPCRR & CCTGTATGCACATTTCCATTCCGCC & KO screening \\
\hline \multicolumn{3}{|c|}{ CYP53A26 KNOCKOUT } \\
\hline P8F & CCGTCATTGTCCCGAGCCAAGAA & $\begin{array}{l}\text { KO strain } \\
\text { construction }\end{array}$ \\
\hline P8R & TGGCAACGGATGCAAAGACCAAGAC & $\begin{array}{l}\text { KO strain } \\
\text { construction }\end{array}$ \\
\hline P8KOF & CTGGACGCCGTCATTCCCGAG & $\begin{array}{l}\text { KO strain } \\
\text { construction }\end{array}$ \\
\hline P8KOR & CGGGTTCTCGATTCGGCTCTTG & $\begin{array}{l}\text { KO strain } \\
\text { construction }\end{array}$ \\
\hline P8RTPCRF & ATTCGGCATGTTGGCGAGTGGTAT & KO screening \\
\hline P8RTPCRR & AGGTCGGCACGCTCAAGACGGT & KO screening \\
\hline
\end{tabular}

(Continued)
Table 3 | Continued

\begin{tabular}{|c|c|c|}
\hline Name & Sequence $\left(5^{\prime}\right.$ to $\left.3^{\prime}\right)$ & Use \\
\hline \multicolumn{3}{|c|}{ CYP655C1 KNOCKOUT } \\
\hline $\mathrm{Ep}(2) \mathrm{F}$ & GCCTCACGCAACTACTCAGCCTTTCATC & $\begin{array}{l}\text { KO strain } \\
\text { construction }\end{array}$ \\
\hline $\operatorname{Ep}(2) R$ & CGCAGACTCATTCTGGACCATCATTTG & $\begin{array}{l}\text { KO strain } \\
\text { construction }\end{array}$ \\
\hline $\mathrm{Ep}(2) \mathrm{KOF}$ & CAAACTATGGCGGCTACCGGT & $\begin{array}{l}\text { KO strain } \\
\text { construction }\end{array}$ \\
\hline $\mathrm{Ep}(2) \mathrm{KOR}$ & GTCGTGAGCTAGGAATCTGCGCA & $\begin{array}{l}\text { KO strain } \\
\text { construction }\end{array}$ \\
\hline Ep(2)RTPCRF & СTCCTAGACAGCGTGAGCCTCCCAT & KO screening \\
\hline Ep(2)RTPCRR & GGTGCTGCCTGATGGGCTCGAC & KO screening \\
\hline \multicolumn{3}{|c|}{ CYP5337A1 EXPRESSION } \\
\hline $\mathrm{EP}(4) \mathrm{F}$ & GGATTAATAATGGCGCTCACTGCTATCCT & \\
\hline $\mathrm{EP}(4) \mathrm{R}$ & $\begin{array}{l}\text { GGGTTAATTTAGTGGTGGTGGTGGTGG } \\
\text { TGGACAGCCTCGTGCAGGCGGAC }\end{array}$ & \\
\hline \multicolumn{3}{|c|}{ CYP617N1 EXPRESSION } \\
\hline $\mathrm{EP}(7) \mathrm{F}$ & GGATTAATAATGGCCGTGGTTGAGCTC & \\
\hline $\mathrm{EP}(7) \mathrm{R}$ & $\begin{array}{l}\text { GGGTTAATTTAGTGGTGGTGGTGGTGGT } \\
\text { GTCGCCTAGCCAGTGCATCTC }\end{array}$ & \\
\hline \multicolumn{3}{|c|}{ CYP53A26 EXPRESSION } \\
\hline $\mathrm{EP}(8) \mathrm{F}$ & $\begin{array}{l}\text { GGATTAATAATGGCTCTCGGCCAACTT } \\
\text { GCC }\end{array}$ & \\
\hline $\mathrm{EP}(8) \mathrm{R}$ & $\begin{array}{l}\text { GGGTTAATTTAGTGGTGGTGGTGGTGGT } \\
\text { GTTGCAGCTTTTCTTCTGCATTCTG }\end{array}$ & \\
\hline ActinF & TTGGTGCGAAACTTCAGCGTCTAGTC & RT-PCR \\
\hline ActinR & TCCAGCAAATGTGGATCTCCAAGCAG & \\
\hline
\end{tabular}

\section{HETEROLOGOUS EXPRESSION OF B. bassiana CYTOCHROME P450s IN YEAST}

The coding region of CYP5337A1, CYP617N1, CYP53A26, and CYP584Q1 genes were cloned from a $B$. bassiana cDNA library by PCR using primer pairs as listed in Table 3. The resultant PCR product corresponding to each gene was designed to contain an 18 bp ( 6 amino acid) histidine tag and the products were cloned into pYeDP60 under the control of a GAL1 promoter. The sequence integrity of plasmid inserts were confirmed by sequencing and plasmids were then transformed into S. cerevisiae WAT11, a yeast strain engineered and optimized for cytochrome P450 expression, using a lithium acetate protocol (Pompon et al., 1996). Transformants were selected on YNB w/o amino acids, $2 \%$ glucose and auxotrophic supplements and the expression strain designated as Sc-Bbcyp5337a1, Sc-Bbcyp617N1, Sc-Bbcyp53a26, and $S c$-Bbcyp584q1, respectively.

Yeast cultures were grown and heterologous expression of each CYP (CYP5337A1, CYP617N1, CYP53A26, and CYP584Q1) was induced as described in Pompon et al. (Pompon et al., 1996) from one isolated transformed colony. Briefly, after growth, cells were harvested by centrifugation and manually broken with glass beads $(0.45 \mathrm{~mm}$ diameter) in $50 \mathrm{mM}$ Tris- $\mathrm{HCl}$ buffer $(\mathrm{pH} 7.5)$ containing $1 \mathrm{mM}$ EDTA and $600 \mathrm{mM}$ sorbitol. The homogenate was centrifuged for $10 \mathrm{~min}$ at $10,000 \mathrm{~g}$. The resulting supernatant was centrifuged for $1 \mathrm{~h}$ at $100,000 \mathrm{~g}$. The pellet consisting of 
microsomal membranes was resuspended in $50 \mathrm{mMTris}-\mathrm{HCl}(\mathrm{pH}$ 7.4), $1 \mathrm{mM}$ EDTA and 30\% (v/v) glycerol with a Potter-Elvehjem homogenizer and stored at $-30^{\circ} \mathrm{C}$. The volume of resuspension buffer is proportional to the weight of yeast pellet: microsomes extracted from $6 \mathrm{~g}$ of yeast are resuspended in $3 \mathrm{ml}$ of buffer. All procedures for microsomal preparation were carried out at $0-4^{\circ} \mathrm{C}$. Western blots were performed using standard protocols. Mouse anti-His monoclonal antibodies were obtained from Invitrogen.

\section{CYP SOLUBILIZATION AND PARTIAL PURIFICATION}

Microsomal fractions were treated with $10 \%(\mathrm{w} / \mathrm{v})$ sodium cholate solution (final concentration $1 \% \mathrm{w} / \mathrm{v}$ ) for $30 \mathrm{~min}$ at $4^{\circ} \mathrm{C}$, in order to solubilize proteins from membranes. After ultracentrifugation $\left(100,000 \mathrm{~g}, 60 \mathrm{~min}, 4^{\circ} \mathrm{C}\right)$ supernatants were loaded onto Ni-NTA columns and purified by immobilized metal-ion affinity chromatography (IMAC) following standards protocols. Eluted fractions were analyzed by SDS-PAGE. Fractions containing the tagged protein were pooled, concentrated, and assayed for P450 content.

\section{REFERENCES}

Anderson, S. O., Hojrup, P., and Roepstorff, P. (1995). Insect cuticular proteins. Insect Biochem. Mol. Biol. 25, 153-176.

Asiimwe, T., Krause, K., Schlunk, I., and Kothe, E. (2012). Modulation of ethanol stress tolerance by aldehyde dehydrogenase in the mycorrhizal fungus Tricholoma vaccinum. Mycorrhiza 22, 1-14.

Bagnères, A. G., and Blomquist, G. J. (2010). "Site of synthesis, mechanism of transport and selective deposition of hydrocarbons," in Insect Hydrocarbons: Biology, Biochemistry and Chemical Ecology, eds G. J. Blomquist and A. G. Bagnères (New York, NY: Cambridge University Press), 75-99.

Berbee, M. L., and Taylor, J. W. (2001). "Fungal molecular evolution: gene trees and geologic time," in The Mycota VII Part, B, eds McLaughlin, McLaughlin, and Lemke (Berlin Heidelberg: $\quad$ Springer-Verlag), 229-245.

Bidochka, M. J., Clark, D. C., Lewis, M. W., and Keyhani, N. O. (2010). Could insect phagocytic avoidance by entomogenous fungi have evolved via selection against soil amoeboid predators? Microbiology 156, 2164-2171.

Bidochka, M. J., and Khachatourians, G. G. (1991). The implication of metabolic acids produced by Beauveria bassiana in pathogenesis of the migratory grasshopper, Melanoplus sanguinipes. J. Invertebr. Pathol. 58, 106-117.
Binnington, K., and Retnakaran, A. (1991). Physiology of the Insect Epidermis. Melbourne: CSIRO Publications.

Blomquist, G. J., and Dillwith, J. W. (1985). "Cuticular lipids," in Comprehensive Insect Physiology, Biochemistry, and Pharmacology, eds G. A. Kerkut and L. I. Gilbert (Oxford: Pergamon Press), 117-154.

Blomquist, G. J., Nelson, D. R., and Derenobales, M. (1987). Chemistry, biochemistry, and physiology of insect cuticular lipids. Arch. Insect Biochem. Physiol. 6, 227-265.

Blomquist, G. J., Tillman-Wall, J. A., Guo, L., Quilici, D. R., Gu, P., and Schal, C. (1993). "Hydrocarbon and hydrocarbonderived sex pheromones in insects," in Biochemistry and Endocrine Regulation, eds D. W. StanleySamuelson and D. R. Nelson (Lincoln, NE: University of Nebraska Press), 317-351.

Boucias, D. G., and Pendland, J. C. (1984). Nutritional requirements for conidial germination of several host range pathotypes of the entomopathogenic fungus Nomuraea rileyi. J. Invertebr. Pathol. 43, 288-292.

Boucias, D. G., Pendland, J. C., and Latge, J. P. (1988). Nonspecific factors involved in attachment of entomopathogenic Deuteromycetes to host insect cuticle. Appl. Environ. Microbiol. 54, 1795-1805.

Buckner, J. S. (1993). "Cuticular polar lipids of insects," in Insect Lipids:

\section{MEASUREMENT OF REDUCED CARBON MONOXIDE (CO) DIFFERENCE SPECTRA}

The reduced $\mathrm{CO}$ difference spectra were measured in an Ultrospec 2100 pro spectrophotometer (Biochrom Ltd., Cambridge, UK) as described (Schenkman and Jansson, 2006), with minimal modifications. Briefly, samples were diluted to $1 \mathrm{mg}$ $\mathrm{ml}^{-1}$ protein, CO was slowly burbled into the cuvet for about $30 \mathrm{~s}$, and a few milligrams of sodium dithionite were added. After stirring and waiting $1 \mathrm{~min}$, the difference spectrum was recorded between 400 and $500 \mathrm{~nm}$. Protein concentrations were determined by the Pierce bicinchoninic acid microassay, using bovine serum albumin as standard.

\section{ACKNOWLEDGMENTS}

This work was supported in part by an NSF grant IOS-1121392 to Nemat O. Keyhani. Almudena Ortiz-Urquiza was supported in part by a Fellowship from the Spanish Ministry of Education (EX2010-1098). This work was also supported in part by grants from ANPCyT (PICT 2008 0802) and CONICET (PIP 0237) to Nicolás Pedrini.

Chemistry, Biochemistry and Biology, eds D. W. Stanley-Samuelson and D. R. Nelson (Lincoln, NE: University of Nebraska Press), 227-270.

Cameotra, S. S., Singh, H. D., Hazarika, A. K., and Baruah, J. N. (1983). Mode of uptake of insoluble solid substrates by microorganisms 2. Uptake of solid normal-alkanes by yeast and bacterial species. Biotechnol. Bioeng. 25, 2945-2956.

Charnley, A. K., and St Leger, R. (1991). "The role of cuticle degrading enzymes in fungal pathogenesis of insects," in The Fungal Spore and Disease Initiation, eds G. T. Cole and H. C. Hoch (New York, NY: Plenum Press), 267-286.

Chino, H., and Kitazawa, K. (1981). Diacylglycerol-carrying lipoprotein of hemolymph of the locust and some insects. J. Lipid Res. 22, 1042-1052.

Cho, E. M., Boucias, D., and Keyhani, N. O. (2006a). EST analysis of cDNA libraries from the entomopathogenic fungus Beauveria (Cordyceps) bassiana. II. Fungal cells sporulating on chitin and producing oosporein. Microbiology 152, 2855-2864.

Cho, E. M., Liu, L., Farmerie, W. and Keyhani, N. O. (2006b). EST analysis of cDNA libraries from the entomopathogenic fungus Beauveria (Cordyceps) bassiana. I. Evidence for stage-specific gene expression in aerial conidia, in vitro blastospores and submerged conidia. Microbiology 152, 2843-2854.
Clarkson, J. M., and Charnley, A. K. (1996). New insights into the mechanisms of fungal pathogenesis in insects. Trends Microbiol. 4, 197-203.

Cooney, J. J., Siporin, C., and Smucker, R. A. (1980). Physiological and cytological responses to hyd rocarbons by the hydrocarbon-using fungus Cladosporium resinae. Botanica Marina 23, 227-232.

Crespo, R., Juarez, M. P., and Cafferata, L. F. R. (2000). Biochemical interaction between entomopathogenous fungi and their insect-host-like hydrocarbons. Mycologia 92, 528-536.

Crespo, R., Juarez, M. P., Dal Bello, G. M., Padin, S., Fernandez, G. C., and Pedrini, N. (2002). Increased mortality of Acanthoscelides obtectus by alkane-grown Beauveria bassiana. Biocontrol 47, 685-696.

Crespo, R., Pedrini, N., Juarez, M. P., and Dal Bello, G. M. (2008). Volatile organic compounds released by the entomopathogenic fungus Beauveria bassiana. Microbiol. Res. 163, 148-151.

Deng, J., Carbone, I., and Dean, R. A. (2007). The evolutionary history of Cytochrome P450 genes in four filamentous Ascomycetes. BMC Evol. Biol. 7:30. doi: 10.1186/1471-21487-30

Dereeper, A., Audic, S., Claverie, J.-M., and Blanc, G. (2010). BLASTEXPLORER helps you building datasets for phylogenetic analysis. BMC Evol. Biol. 10:8. doi: 10.1186/1471-2148-10-8 
Dereeper, A., Guignon, V., Blanc, G., Audic, S., Buffet, S., Chevenet, F., et al. (2008). Phylogeny.fr: robust phylogenetic analysis for the non-specialist. Nucleic Acids Res. 36, 465-469.

Dettner, K., and Liepert, C. (1994). Chemical mimicry and camouflage. Annu. Rev. Entomol. 39, 129-154.

Doddapaneni, H., Chakraborty, R., and Yadav, J. S. (2005). Genomewide structural and evolutionary analysis of the P450 monooxygenase genes (P450ome) in the white rot fungus Phanerochaete chrysosporium: evidence for gene duplications and extensive gene clustering. BMC Genomics 6:92. doi: 10.1186/1471-2164-6-92

Espelie, K., Chapman, R. F., and Sword, G. A. (1994). Variation in the surface lipids of the grasshopper, Schistocerca americana (Drury). Biochem. Syst. Ecol. 22, 563-575.

Fan, Y., Borovsky, D., Hawkings, C., Ortiz-Urquiza, A., and Keyhani, N. O. (2012a). Exploiting host molecules to augment mycoinsecticide virulence. Nat. Biotechnol. 30, 35-37.

Fan, Y., Pereira, R. M., Kilic, E., Casella, G., and Keyhani, N. O. (2012b). Pyrokinin beta-neuropeptide affects necrophoretic behavior in fire ants (S. invicta), and expression of betaNP in a mycoinsecticide increases its virulence. PLoS ONE 7:e26924. doi: 10.1371/journal.pone.0026924

Fan, Y., Zhang, S., Kruer, N., and Keyhani, N. O. (2011). Highthroughput insertion mutagenesis and functional screening in the entomopathogenic fungus Beauveria bassiana. J. Invertebr. Pathol. 106, 274-279.

Ferron, P. (1981). "Pest control by the fungi Beauveria and Metarhizium," in Microbial Control of Pests and Plant Diseases 1970-1980, ed H. D. Burges (New York, NY: Academic Press), 465-482.

Fickers, P., Benetti, P. H., Wache, Y., Marty, A., Mauersberger, S., Smit, M. S., et al. (2005). Hydrophobic substrate utilisation by the yeast Yarrowia lipolytica, and its potential applications. Fems Yeast Res. 5, 527-543.

Flipphi, M., Mathieu, M., Cirpus, I., Panozzo, C., and Felenbok, B. (2001). Regulation of the aldehyde dehydrogenase gene (aldA) and its role in the control of the coinducer level necessary for induction of the ethanol utilization pathway in Aspergillus nidulans. J. Biol. Chem. 276, 6950-6958.

Freimoser, F. M., Hu, G., and St. Leger, R. J. (2005). Variation in gene expression patterns as the insect pathogen Metarhizium anisopliae adapts to different host cuticles or nutrient deprivation in vitro. Microbiology 151, 361-371.

Gao, Q., Jin, K., Ying, S.-H., Zhang, Y., Xiao, G., Shang, Y., et al. (2011). Genome sequencing and comparative transcriptomics of the model entomopathogenic fungi Metarhizium anisopliae and $M$. acridum. PLoS Genetics 7:e1001264. doi: 10.1371/journal.pgen.1001264

Gartner, C. A., Thompson, S. J., Rettie, A. E., and Nelson, S. D. (2001). Human aromatase in high yield and purity by perfusion chromatography and its characterization by difference spectroscopy and mass spectrometry. Protein Expr. Purif. 22, 443-454.

Gibbs, A., and Mousseau, T. A. (1994). Thermal acclimation and genetic variation in cuticular lipids of the lesser migratory grasshopper (Melanoplus sanguinipes) - effects of lipid composition on biophysical properties. Physiol. Zool. 67, 1523-1543.

Gibbs, A., Mousseau, T. A., Dingle, H., and Crowe, J. H. (1990). Genetic and acclimatory variation in cuticle lipids of grasshoppers, Melanoplus sanguinipes. Am. Zool. 30, A33-A33.

Goettel, M. S., Inglis, G. D., and Wraight, S. P. (2000). "Fungi," in Field Manual of Techniques in Invertebrate Pathology, eds L. A. Lacey and H. K. Kaya (Netherlands: Kluwer Academic), 255-282.

Golebiowski, M., Malinski, E., Bogus, M. I., Kumirska, J., and Stepnowski, P. (2008). The cuticular fatty acids of Calliphora vicina, Dendrolimus pini and Galleria mellonella larvae and their role in resistance to fungal infection. Insect Biochem. Mol. Biol. 38, 619-627.

Goma, G., Pareilleux, A., and Durand, G. (1973). Cinetique de degradation des hydrocarbures par Candida lipolytica. Arch. Mikrobiol. 88, 97-109.

Gu, X., Quilici, D., Juarez, P., Blomquist, G. J., and Schal, C. (1995). Biosynthesis of hydrocarbons and contact sex pheromone and their transport by lipophorin in females of the German cockroach (Blattella germanica). J. Insect Physiol. 41, 257-267.

Hackman, R. H. (1984). "Cuticle: biochemistry," in Biology of the Integument, eds J. Bereiter-Hahn, A. G. Mateltsy, and K. S. Richards (Berlin: Springer-Verlag), 583-610.

Harada, N. (1998). Novel properties of human placental aromatase as cytochrome P450. Purification and characterization of a unique form of aromatase. J. Biochem. 103, 106-113.

Holder, D. J., and Keyhani, N. O. (2005). Adhesion of the entomopathogenic fungus Beauveria (Cordyceps) bassiana to substrata. Appl. Environ. Microbiol. 71, 5260-5266.

Howard, R. W. (1993). "Cuticular hydrocarbons and chemical communication," in Insect Lipids: Chemistry, Biochemistry and Biology, eds D. R. Stanley-Samuelson and D. R. Nelson (Lincoln, NE: University of Nebraska Press), 179-226.

Howard, R. W., and Blomquist, G. J. (2005). Ecological, behavioral, and biochemical aspects of insect hydrocarbons. Annu. Rev. Entomol. 50, 371-393.

Hung, C. Y., and Boucias, D. G. (1992). Influence of Beauveria bassiana on the cellular defense response of the Beet Armyworm, Spodoptera exigua. J. Invertebr. Pathol. 60, 152-158.

Inglis, G. D., Goettel, M. S., Butt, T. M., and Strasser, H. (2001). "Use of hyphomycetous fungi for managing insect pests," in Field Manual of Techniques in Invertebrate Pathology, eds L. A. Lacey and H. K. Kaya (Netherlands: Kluwer Academic), 651-679.

Ito, H., Fukuda, Y., Murata, K., and Kimura, A. (1983). Transformation of intact yeast cells treated with alkali cations. J. Bacterol. 153, 163-168.

Jarrold, S. L., Moore, D., Potter, U. and Charnley, A. K. (2007). The contribution of surface waxes to pre-penetration growth of an entomopathogenic fungus on host cuticle. Mycol. Res. 111, 240-249.

Juárez, M. P., Pedrini, N., Crespo, R., (2004). "Mycoinsecticides against Chagas disease vectors: biochemistry involved in insect host hydrocarbon degradation," in Multidisciplinarity for Parasites, Vectors and Parasitic Diseases, ed S. Mas-Comas (Bologna: Monduzzi Editore), 137-142.

Kappeli, O., Walther, P., Mueller, M., and Fiechter, A. (1984). Structure of the cell-surface of the yeast Candida tropicalis and its relation to hydrocarbon transport. Arch. Microbiol. 138, 279-282.

Kerwin, J. L. (1984). Fatty acid regulation of the germination of Erynia variabilis conidia on adults and puparia of the lesser housefly, Fannia canicularis. Can. J. Microbiol. 30, 158-161.
Khachatourians, G. G. (1996) "Biochemistry and Molecular Biology of Entomopathogenic Fungi," in The Mycota VI: Human and Animal Relationships, eds D. H. Howard and J. D. Miller (Berlin, Heidelberg: $\quad$ Springer-Verlag), 331-363.

Kirkland, B. H., Cho, E. M., and Keyhani, N. O. (2004a). Differential susceptibility of Amblyomma maculatum and Amblyomma americanum (Acari: Ixodidea) to the entomopathogenic fungi Beauveria bassiana and Metarhizium anisopliae. Biol. Control 31, 414-421.

Kirkland, B. H., Westwood, G. S., and Keyhani, N. O. (2004b). Pathogenicity of entomopathogenic fungi Beauveria bassiana and Metarhizium anisopliae to Ixodidae tick species Dermacentor variabilis, Rhipicephalus sanguineus, and Ixodes scapularis. J. Med. Entomol. 41, 705-711.

Kirkland, B. H., Eisa, A., and Keyhani, N. O. (2005). Oxalic acid as a fungal acaracidal virulence factor. J. Med. Entomol. 42, 346-351.

Koidsumi, K. (1957). Antifungal action of cuticular lipids in insects. J. Insect Physiol. 1, 40-51.

Kurtti, T. J., and Keyhani, N. O. (2008). Intracellular infection of tick cell lines by the entomopathogenic fungus Metarhizium anisopliae. Microbiology 154, 1700-1709.

Latge, J. P., Sampedro, L., Brey, P., and Diaquin, M. (1987). Aggressiveness of Conidiobolus obscurus against the pea aphid - influence of cuticular extracts on ballistospore germination of aggressive and nonaggressive Strains. J. Gen. Microbiol. 133, 1987-1997.

Lau, S. M., Harder, P. A., and O'Keefe, D. P. (1993). Low carbon monoxide affinity allene oxide synthase is the predominant cytochrome P450 in many plant tissues. Biochemistry 32, 1945-1950.

Lecuona, R., Clement, J. L., Riba, G., Joulie, C., and Juarez, P. (1997). Spore germination and hyphal growth of Beauveria sp on insect lipids. J. Econ. Entomol. 90, 119-123.

Lecuona, R., Riba, G., Cassier, P., and Clement, J. L. (1991). Alterations of insect epicuticular hydrocarbons during infection with Beauveria bassiana or $B$. brongniartii. J. Invertebr. Pathol. 58, 10-18.

Lewis, M. W., Robalino, I. V., and Keyhani, N. O. (2009). Uptake of the fluorescent probe FM4-64 by hyphae and haemolymphderived in vivo hyphal bodies of the entomopathogenic fungus 
Beauveria bassiana. Microbiology 155, 3110-3120.

Lindley, N. D. (1995). Bioconversion and biodegradation of aliphatichydrocarbons. Can. J. Bot. 73, S1034-S1042.

Lindley, N. D., and Heydeman, M. T. (1986). The uptake of normalalkanes from alkane mixtures during growth of the hydrocarbonutilizing fungus Cladosporium resinae. Appl. Microbiol. Biotechnol. 23, 384-388.

Liu, D., Coloe, S., Baird, R., and Pedersen, J. (2000). Rapid minipreparation of fungal DNA for PCR. J. Clin. Microbiol. 38, 471-471.

Lockey, K. H. (1988). Lipids of the insect cuticle - origin, composition and function. Comp. Biochem. Physiol. B Biochem. Mol. Biol. 89, 595-645.

Lockey, K. H., and Oraha, V. S. (1990). Cuticular lipids of adult Locusta migratoria migratoriodes ( $\mathrm{R}$ and F), Schistocerca gregaria (Forskal) (Acrididae) and Other Orthopteran Species.2. Hydrocarbons. Comp. Biochem. Physiol. B Biochem. Mol. Biol. 95, 721-744.

Lord, J. C., and Howard, R. W. (2004). A proposed role for the cuticular fatty amides of Liposcelis bostrychophila (Psocoptera: Liposcelidae) in preventing adhesion of entomopathogenic fungi with dry-conidia. Mycopathologia 158, 211-217.

Marchler-Bauer, A., Lu, S., Anderson, J. B., Chitsaz, F., Derbyshire, M. K., Deweese-Scott, C., et al. (2011). CDD: a conserved domain database for the functional annotation of proteins. Nucleic Acids Res. 39, D225-D229.

Meisel, M. N., Medvedeva, G. A., Kozlova, T. M., Domoshnikova, N. A., Zaikina, A. I., and Fedoseeva, G. E. (1973). "Regularities of penetration into yeast cells of higher fatty acids and hydrocarbons, their intracellular migration and concentration," in Proceedings of the 3rd International Specilized Symposium on Yeast, eds H. Suomalainen and C. Waller (Helsinki: Otaniemi), 149-168.

Metzenberg, R. L., Jacobson, D. J., and Bertrand, H. (2000). Making the selective agent for the Bar plasmids, phosphinothricin (glufosinate) affordable for routine use. Fungal Genet. Newsl. 47, 79-80.

Montellano, P. R. O. D. (ed.). (2005). Cytochrome P450: Structure, Mechanism, and Biochemistry. New York, NY: Kluwer Academic/Plenum.
Napolitano, R., and Juarez, M. P. (1997). Entomopathogenous fungi degrade epicuticular hydrocarbons of Triatoma infestans. Arch. Biochem. Biophys. 344, 208-214.

Nelson, D. R. (1993). "Methylbranched lipids in insects," in Insect lipids: Chemistry, Biochemistry and Biolgy, eds D. W. Stanley-Samuelson and D. R. Nelson (Lincoln, NE: University of Nebraska Press), 271-315.

Nelson, D. R., Koymans, L., Kamataki, T., Stegeman, J. J., Feyereisen, R., Waxman, D. J., et al. (1996). P450 superfamily: update on new sequences, gene mapping, accession numbers and nomenclature. Pharmacogenetics 6, 1-42.

Nelson, D. R. (1998). Metazoan cytochrome P450 evolution. Comp. Biochem. Physiol. C Pharmacol. Toxicol. Endocrinol. 121, 15-22.

Nelson, D. R. (1999). Cytochrome P450 and the individuality of species. Arch. Biochem. Biophys. 369, $1-10$.

Nelson, D. R. (2009). The cytochrome P450 homepage. Hum. Genomics 4, 59-65.

Nelson, D. R., and Blomquist, G. J. (1995). "Insect Waxes," in Waxes: Chemistry, Molecular Biology, and Functions, ed R. J. Hamilton (Dundee: The Oily Press, Ltd.), 1-90.

Noble-Nesbitt, J. I. E. (1991). "Cuticular permeability and its control," in Physiology of the Insect Epidermis, eds K. Binnington and A. Retnakaran (Melbourne: CSIRO), 252-283.

Padilla-Guerrero, I. E., Barelli, L., Gonzalez-Hernandez, G. A., TorresGuzman, J. C., and Bidochka, M. J. (2011). Flexible metabolism in Metarhizium anisopliae and Beauveria bassiana: role of the glyoxylate cycle during insect pathogenesis. Microbiology 157, 199-208.

Pedrini, N., Crespo, R., and Juarez, M. P. (2007). Biochemistry of insect epicuticle degradation by entomopathogenic fungi. Comp. Biochem. Physiol. C Toxicol. Pharmacol. 146, 124-137.

Pedrini, N., Juárez, M., Crespo, R., and De Alaniz, M. (2006). Clues on the role of Beauveria bassiana catalases in alkane degradation events. Mycologia 98, 528-534.

Pedrini, N., Mijailovsky, S. J., Girotti, J. R., Stariolo, R., Cardozo, R. M., Gentile, A., et al. (2009). Control of pyrethroid-resistant chagas disease vectors with entomopathogenic fungi. PLoS Negl. Trop. Dis. 3:e434. doi: 10.1371/journal.pntd.0000434
Pedrini, N., Zhang, S., Juárez, M., and Keyhani, N. O. (2010). Molecular characterization and expression analysis of a suite of cytochrome P450 enzymes implicated in insect hydrocarbon degradation in the entomopathogenic fungus Beauveria bassiana. Microbiology 156, 2549-2557.

Pendland, J. C., Hung, S. Y., and Boucias, D. G. (1993). Evasion of host defense by in vivo-produced protoplast-like cells of the insect mycopathogen Beauveria bassiana. J. Bacteriol. 175, 5962-5969.

Pompon, D., Louerat, B., Bronine, A., and Urban, P. (1996). Yeast expression of animal and plant P450s in optimized redox environments. Cytochrome P450(Pt B 272), 51-64.

Qiu, Y., Tittiger, C., Wicker-Thomas, C., Le Goff, G., Young, S., Wajnberg, E., et al. (2012). An insect-specific P450 oxidative decarbonylase for cuticular hydrocarbon biosynthesis. Proc. Natl. Acad. Sci. U.S.A. 109, 14858-14863.

Reddy, P., Singh, H., Roy, P., and Baruah, J. (1982). Predominant role of hydrocarbon solubilization in the microbial uptake of hydrocarbons. Biotechnol. Bioeng. 24, 1241-1269.

Renobales, M., Nelson, D. R., and Blomquist, G. J. (1991). "Cuticular Lipids," in Physiology of the Insect Epidermis, eds K. Binnington and A. Retnakaran (Melbourne: CSIRO Publications), 240-251.

Riley, P. A. (1997). Melanin. In.t J. Biochem. Cell Biol. 29, 1235-1239.

Roberts, D. W., and Humber, R. A. (1981). "Entomogenous Fungi," in Biology of Conidial Fungi, eds G. T. Cole and B. Kendrick (New York, NY: Academic Press), 201-236.

Rojo, F. (2010). "Enzymes for aerobic degradation of alkanes," in Handbook of Hydrocarbon and Lipid Microbiology, ed K. N. Timmis (Berlin Heidelberg: Springer-Verlag), 781-797.

Saito, T., and Aoki, J. (1983). Toxicity of free fatty acids on the larval surfaces of 2 Lepidopterous insects towards Beauveria bassiana (Bals) Vuill and Paecilomyces fumoso-roseus (Wize) Brown Et Smith (Deuteromycetes, Moniliales). Appl. Entomol. Zool. 18, 225-233.

Schal, C., Sevala, V. L., Young, H. P., and Bachmann, J. A. S. (1998). Sites of synthesis and transport pathways of insect hydrocarbons: cuticle and ovary as target tissues. Am. Zool. 38, 382-393.

Scheller, U., Zimmer, T., Becher, D., Schauer, F., and Schunck, W. H. (1998). Oxygenation cascade in conversion of n-alkanes to alpha, omega-dioic acids catalyzed by cytochrome p450 52A3. J. Biol. Chem. 273, 32528-32534.

Schenkman, J. B., and Jansson, I. (2006). "Spectral analyses of cytochromes P450," in Methods in Molecular Biology: Cytochrome P450 Protocols, eds I. R. Phillips and E. A. Shepard (New Jersey, NJ: Humana Press), 11-18.

Scholte, E. J., Ng'habi, K., Kihonda, J., Takken, W., Paaijmans, K., Abdulla, S., et al. (2005). An entomopathogenic fungus for control of adult African malaria mosquitoes. Science 308, 1641-1642.

Singer, T. L. (1998). Roles of hydrocarbons in the recognition systems of insects. Am. Zool. 38, 394-405.

Singh, H. (2006). "Fungal metabolism of petroleum hydrocarbons," in Mycoremediation: Fungal Bioremediation (Hoboken, NJ: John Wiley and Sons), 115-148.

Smith, R. J., and Grula, E. A. (1982). Toxic components on the larval surface of the Corn-Earworm (Heliothis zea) and their effects on germination and growth of Beauveria bassiana. J. Invertebr. Pathol. 39, 15-22.

Steinhaus, E. A. (1956). Microbial control-The emergence of an idea: a brief history of insect pathology through the nineteenth century. Hilgardia 26, 107-160.

St Leger, R. (1991). "Integument as a Barrier to Microbial Infections," in Physiology of the Insect Epidermis, eds K. Binnington and A. Retnakaran (Melbourne: CSIRO Publications), 284-306.

Sweigard, J., Chumley, F., Carroll, A., Farrall, L., and Valent, B. (1997). A series of vectors for fungal transformation. Fungal Genet. Newsl. 44, 52-53.

Takai, H., Iwama, R., Kobayashi, S., Horiuchi, H., Fukuda, R., and Ohta, A. (2012). Construction and characterization of a Yarrowia lipolytica mutant lacking genes encoding cytochromes P450 subfamily 52. Fungal Genet. Biol. 49, 58-64.

Van Beilen, J. B., Li, Z., Duetz, W. A., Smits, T. H. M., and Witholt, B. (2003). Diversity of alkane hydroxylase systems in the environment. Oil Gas Sci. Technol. 58, 427-440.

Van Heusden, M. C., Van Der Horst, D. J., Ka-Wooya, J. K., and Law, J. H. (1991). In vivo and in vitro loading of lipid by artificially lipiddepleted lipophorins: evidence for the role of lipophorin as a reusable lipid shuttle. J. Lipid Res. 32, 1789-1794.

Van Valen, L. (1973). A new evolutionary law. Evol. Theory 1, 1-30. 
Wanchoo, A., Lewis, M. W., and Keyhani, N. O. (2009). Lectin mapping reveals stage-specific display of surface carbohydrates in in vitro and haemolymph-derived cells of the entomopathogenic fungus Beauveria bassiana. Microbiology 155, 3121-3133.

Wang, Z.-L., Zhang, L.-B., Ying, S.-H., and Feng, M.-G. (2012). Catalases play differentiated roles in the adaptation of a fungal entomopathogen to environmental stresses. Environ. Microbiol. 15, 409-418.

Xiao, G., Ying, S.-H., Zheng, P., Wang, Z.-L., Zhang, S., Xie, X.-Q., et al. (2012). Genomic perspectives on the evolution of fungal entomopathogenicity in Beauveria bassiana. Sci. Rep. 2, 483.
Yadav, J. S., Doddapaneni, H., and Subramanian, V. (2006). P450ome of the white rot fungus Phanerochaete chrysosporium: structure, evolution and regulation of expression of genomic P450 clusters. Biochem. Soc. Trans. 34, 1165-1169.

Zhang, S., Fan, Y., Xia, Y. X., and Keyhani, N. O. (2010). Sulfonylurea resistance as a new selectable marker for the entomopathogenic fungus Beauveria bassiana. Appl. Microbiol. Biotechnol. 87, 1151-1156.

Zhang, S., Widemann, E., Bernard, G., Lesot, A., Pinot, F., Pedrini, N., et al. (2012). CYP52X1, representing new cytochrome P450 subfamily, displays fatty acid hydroxylase activity and contributes to virulence and growth on insect cuticular substrates in entomopathogenicfungus Beauveria bassiana. J. Biol. Chem. 287, 13477-13486.

Conflict of Interest Statement: The authors declare that the research was conducted in the absence of any commercial or financial relationships that could be construed as a potential conflict of interest.

Received: 13 December 2012; paper pending published: 04 January 2013; accepted: 30 January 2013; published online: 15 February 2013.

Citation: Pedrini N, Ortiz-Urquiza A, Huarte-Bonnet $C$, Zhang $S$ and Keyhani
NO (2013) Targeting of insect epicuticular lipids by the entomopathogenic fungus Beauveria bassiana: hydrocarbon oxidation within the context of a hostpathogen interaction. Front. Microbio. 4:24. doi: 10.3389/fmicb.2013.00024

This article was submitted to Frontiers in Microbiological Chemistry, a specialty of Frontiers in Microbiology.

Copyright (C) 2013 Pedrini, OrtizUrquiza, Huarte-Bonnet, Zhang and Keyhani. This is an open-access article distributed under the terms of the Creative Commons Attribution License, which permits use, distribution and reproduction in other forums, provided the original authors and source are credited and subject to any copyright notices concerning any third-party graphics etc. 